\title{
Grafting Improves Growth and Nitrogen-use Efficiency by Enhancing NO3- Uptake, Photosynthesis, and Gene Expression of Nitrate Transporters and Nitrogen Metabolizing Enzymes in Watermelon Under Low Nitrogen
}

\author{
Xiaoling Chen \\ Peijin Guo \\ Zhiyu Wang \\ Jiayi Liang \\ Guohu Li \\ Wenwen He \\ Ai Zhen ( $D$ 81558850@qq.com ) \\ Northwest Agriculture and Forestry University
}

Research Article

Keywords: Watermelon, Grafting, Low-nitrate treatment, NO3- uptake and metabolism, Photosynthesis, Nitrogen-use efficiency

Posted Date: February 3rd, 2022

DOI: https://doi.org/10.21203/rs.3.rs-1231866/v1

License: (c) (i) This work is licensed under a Creative Commons Attribution 4.0 International License. Read Full License 


\section{Abstract}

Background Excessive and insufficient application of $\mathrm{N}$ fertilizer can inhibit plant growth, reduce $\mathrm{N}$-use efficiency (NUE) and lead to production reduction. Watermelon is an important crop that often restricted by inappropriate $\mathrm{N}$ supply. The study aims to test whether grafting with bottle gourd rootstock can improve NUE and growth performance of watermelon under low $\mathrm{N}$ and to clarify the underlying physiological mechanism.

Methods Grafted (self-grafted and rootstock-grafted watermelon) and ungrafted (watermelon and bottle gourd) seedlings were tested respectively, and treated with $9 \mathrm{mM}$ (normal condition) and $4 \mathrm{mM}$ (low N condition) $\mathrm{NO}_{3}{ }^{-}-\mathrm{N}_{\text {concentrations for } 18 \text { days }}$ under hydroponic conditions.

Results The growth and NUE of bottle gourd rootstock-grafted watermelon seedlings increased under low-nitrate, while decreased slightly in self-grafted seedlings compared with control. Rootstock-grafted plants had higher root morphological characteristics, $\mathrm{NO}_{3}{ }^{-}$uptake, photosynthesis, and NUE traits than self-grafted plants under low-nitrate. The expression of nitrate transporter genes NRT1.5 and NRT2.1, and N metabolizing enzyme genes NR, NiR, GS1 and GS2 of rootstock-grafted plants were significantly up-regulated at low-nitrate treatment, which may lead to increased $\mathrm{NO}_{3}{ }^{-}$uptake and metabolism.

Conclusion The bottle gourd rootstock grafting can improve the growth and NUE of watermelon seedlings under low-nitrate treatment. The improved plant performance is attributed to the vigorous root systems and higher $\mathrm{NO}_{3}{ }^{-}$uptake of rootstock roots, and the enhanced $\mathrm{N}$ metabolism and photosynthetic capacity of scion leaves. Grafting with the bottle gourd rootstock may be beneficial to the efficient production of watermelon and economic application of $\mathrm{N}$ fertilizer.

\section{Introduction}

Nitrogen $(\mathrm{N})$ is one of the most important mineral nutrients required by crops, and is a key limiting factor for plant growth and productivity (Iqbal et al. 2019). Many important organic compounds in plants, such as protein, nucleic acid, chlorophyll, enzyme, vitamin and alkaloid, are inseparable from the participation of nitrogen, which plays an important role in plant life activities. In China's greenhouse crop production, large-scale application of $\mathrm{N}$-fertilizer has become the main means to improve crop productivity. However, blindly applying a large amount of $\mathrm{N}$-fertilizer will not only reduce crop N-use efficiency (NUE), increase agricultural production investment, cause serious fertilizer waste, but also lead to a series of environmental problems such as soil secondary salinization (Yuan et al. 2014). Thus, improving NUE and reducing N fertilizer input without decreasing crop growth and yield are imperative and great current challenges for sustainable development of agriculture.

Nitrate nitrogen $\left(\mathrm{NO}_{3}{ }^{-} \mathrm{N}\right)$ is the nitrogen with the highest bioavailability and most absorbed by plants (Zhen et al. 2018). $\mathrm{NO}_{3}{ }^{-}$ uptake by cells is mediated by nitrate transporter proteins (NRTs) located on the plasma membrane of plant roots. This process is completed by high affinity transport systems (HATS) and low affinity transport systems (LATS). HATS and LATS act when the concentration of $\mathrm{NO}_{3}{ }^{-}-\mathrm{N}$ is low $(<1.0 \mathrm{mM})$ and higher than $1.0 \mathrm{mM}$, respectively. These two ways work together to affect NUE by affecting $\mathrm{N}$ transformation. At the molecular level, the genes encoding these transporters play a crucial role in $\mathrm{NO}_{3}{ }^{-}$uptake and transportation from soil to plants ( $\mathrm{Li}$ et al. 2018), and are divided into two gene families: NRT1 (low affinity nitrate transporter genes) and NRT2 (high affinity transporter genes) (Bucher et al. 2014). $\mathrm{NO}_{3}{ }^{-}$absorbed into the plant is reduced to nitrite under the action of nitrate reductase (NR) in the cytoplasm, and nitrite reductase (NiR) further reduces it to ammonium. High concentrations of ammonium are toxic and thus need to be rapidly assimilated by glutamine synthetase (GS) and glutamate synthase (GOGAT) to produce non-toxic organic compounds, such as glutamine and glutamate (Krapp 2015). From this, it is highly likely to promote plant growth and NUE by increasing N uptake and assimilation (Qiao et al. 2019).

Root system is an important organ for plants to absorb inorganic N (Gomes et al. 2021); therefore, its morphological structure and physiological characteristics will affect the ability of plants to obtain N (Jiang et al. 2017), which will directly affect the growth and development of plant shoots. Some studies have reported that grafting can effectively improve the nutrient

Page $2 / 24$ 
absorption of plant roots by "changing roots" (Colla et al. 2011; Özmen et al. 2015; Sallaku et al. 2019). Many suitable rootstocks have been selected for specific scion varieties and used to improve nutrient absorption and utilization, so as to promote plant growth and development (Albacete et al. 2015). Our previous study also demonstrated that the growth and NUE of cucumber seedlings can be promoted by grafting onto N-efficient rootstocks (Liang et al. 2021). Hence, grafting with suitable rootstocks is a very effective and feasible method to improve plant $\mathrm{N}$ uptake and the NUE.

Grafting is a widely used biotechnological tool in vegetable crops and is considered to be a rapid and effective method to protect plants against the effects of soil-borne pathogens (Rahman et al. 2021), and enhance plant's resistance to various abiotic stresses, such as high temperature (De Oliveira et al. 2020), drought (Luo et al. 2020), salinity (Lo'ay and Abo E-Ezz 2021). In addtion, rootstock grafting can also improve the absorption of potassium (K) and magnesium (Mg) by plants (Huang et al. 2013, 2016), and rootstock is the decisive factor for grafted plants to absorb mineral nutrients (Huang et al. 2016; Nawaz et al. 2017; Zhen et al. 2010). Thus, it is valuable to discuss the genotype variation of rootstock effect for understanding the grafting efficacy (particularly in nutrient uptake and transport).

Watermelon [Citrullus lanatus (Thunb.) Matsum. and Nakai.] is one of the most important Cucurbitaceous vegetables and the most popular fruit in summer. As its pulp is rich in many nutrients beneficial to human health, such as water, protein, sugar, minerals, vitamin $\mathrm{C}$ and various amino acids. Watermelon growth requires a large amount of fertilizer, so fertilization is an important means to improve its yield. However, in recent years, the blind application of a large amount of $\mathrm{N}$-fertilizer in protected watermelon cultivation in China has seriously limited the plant growth and reduced the NUE and yield of watermelon. Although several reports suggest that rootstock grafting can alleviate growth inhibition caused by abiotic stresses though improving plant N uptake and utilization (Yang et al. 2013; Özmen et al. 2015; Sallaku et al. 2019), little information is reported about gene expression and related underlying mechanisms, particularly under low $\mathrm{N}$ condition. Moreover, rootstocks with high $\mathrm{N}$ acquisition capacity may enable grafted-plants grow better with less $\mathrm{N}$-fertilizer. However, this possibility needs to be further confirmed. Therefore, the purpose of this study is to investigate 1) whether bottle gourd rootstock grafting can improve the growth and NUE of watermelon seedlings under low $\mathrm{N}$ conditions and 2) whether the enhanced watermelon performance is attributed to higher root $\mathrm{NO}_{3}{ }^{-}$uptake and the improvement of photosynthesis and $\mathrm{N}$ metabolism capacity.

\section{Materials And Methods}

Plant materials and experimental treatments

\section{Experiment 1 response of grafted watermelon to low-nitrate}

The experiment was performed from September to November 2020 in a research greenhouse of Northwest Agricultural and Forestry University in Northwest China (34 16' N, 108 $4^{\prime}$ ' E). Seeds of rootstocks 'Zaojia 8424' [Citrullus lanatus (Thunb.) Matsum. and Nakai., Xinjiang Academy of Agricultural Sciences, China] and 'Jingxinzhen No.1' [Lagenaria siceraria Standl., Beijing Academy of Agricultural Sciences, China] were sown in 50-cell plug trays filled with a 2:1(v/v) mixture of peat and perlite; after 4 days, seeds of scion 'Zaojia 8424' were sown. When the seedlings of rootstock had developed one true leaf, scion was grafted onto the two rootstocks, using the "insertion grafting" procedure as described by Hassell et al. (2008). In order to maintain a relatively high temperature and humidity environment, seedlings were moved to a small arch shed covered with a layer of transparent plastic film and completely shaded for 72 hours. The plastic film was removed for a short time during initial days to control relative humidity, and it was completely removed after 7 days of grafting. The plants were irrigated with tap water before grafting and transplanting to hydroponic cultivation, and no nutrient solution was used during this period. The self-grafted 'Zaojia 8424' plants were used as control. When the two true leaves emerged, the grafted plants were transplanted into $30 \mathrm{~L}$ plastic containers $(85 \mathrm{~cm} \times 40 \mathrm{~cm} \times 20 \mathrm{~cm})$, each containing twelve plants. The plants were directly exposed to two levels of $\mathrm{NO}_{3}{ }^{-}-\mathrm{N}$ concentration [9 $\mathrm{mM}$ (control) and $4 \mathrm{mM}($ low N) ]. These $\mathrm{N}$ levels were decided based on watermelon seedlings growth in our preliminary experiments. The hydroponic nutrient solution refers to the formula of Nawaz et al. (2017). The control nutrient solution was composed of $3.5 \mathrm{mM} \mathrm{Ca}\left(\mathrm{NO}_{3}\right)_{2}, 6 \mathrm{mM} \mathrm{KCl}, 0.5 \mathrm{mM} \mathrm{Ca}\left(\mathrm{H}_{2} \mathrm{PO}_{4}\right)_{2}, 1 \mathrm{mM}$ $\mathrm{MgSO}_{4}, 1 \mathrm{mMMg}\left(\mathrm{NO}_{3}\right)_{2}, 89.7 \mu \mathrm{M} \mathrm{Na}_{2} \mathrm{Fe}-\mathrm{EDTA}, 46.3 \mu \mathrm{M} \mathrm{H}_{3} \mathrm{BO}_{3}, 9.5 \mu \mathrm{MnSO}_{4}, 0.8 \mu \mathrm{MZnSO}_{4}, 0.3 \mu M \mathrm{CuSO}_{4}$, and $0.1 \mu M$ 
$\left(\mathrm{NH}_{4}\right)_{2} \mathrm{MoO}_{4}$. For low $\mathrm{N}$ nutrient solution, $2 \mathrm{mM} \mathrm{Ca}\left(\mathrm{NO}_{3}\right)_{2}$ was used, without $\mathrm{Mg}\left(\mathrm{NO}_{3}\right)_{2}$, whereas the other nutrients were the same as in the control nutrient solution.

In this experiment, four treatments were composed of two grafting combinations and two $\mathrm{N}$ application levels. All treatments were replicated three times with 12 plants in each replicate, and were conducted using a randomized complete block design. The nutrient solution was regularly renewed every 5 days to avoid the deficiency of any specific ions and the pH of the solution was maintained at $6.0 \pm 0.5$. The nutrient solution was aerated with air pumps at 2-hour intervals for 1 hour each time. The temperature of the greenhouse varied from 16 to $30^{\circ} \mathrm{C}$, and the relative humidity varied from 50 to $85 \%$. The plants were harvested at 18 days following $\mathrm{N}$ application.

\section{Experiment 2 response of ungrafted watermelon and bottle gourd to low-nitrate}

In this experiment, ungrafted watermelon (Zaojia 8424) and bottle gourd (Jingxinzhen No.1) were used as materials. Seeds of both were sown in 50-cell plug trays filled with 2:1(v/v) mixture of peat and perlite. The seedlings were irrigated with tap water before transplanting. When the two true leaves emerged, the uniform seedlings were transplanted into $30 \mathrm{~L}$ plastic containers $(85 \mathrm{~cm} \times 40 \mathrm{~cm} \times 20 \mathrm{~cm})$, and each containing 12 plants. Then the plants were directly exposed to $9 \mathrm{mM}^{2}$ and $4 \mathrm{mM} \mathrm{NO}_{3}{ }^{-}-\mathrm{N}$ treatments. The composition and management of nutrient solution were the same as those in Experiment 1. Each treatment was replicated three times with 12 plants in each replication. All treatments were arranged in a randomized complete block design. Plant samples were harvested for measurement of plant growth, root morphology and $\mathrm{NO}_{3}{ }^{-}$content at day 18 of low $\mathrm{N}$ treatment.

\section{Measurement of plant growth}

Five randomly selected plants per treatment were collected to measure plant height (from stem base to growing point) and stem diameter (at $2 \mathrm{~cm}$ above the graft union). The grafted plants were divided into roots, stems and leaves. For ungrafted plants, the part above the cotyledon node was regarded as the "shoot", and the part below was the "root". These organs were rinsed with deionized water, blotted carefully with tissue paper, weighed for fresh weight and then placed in an oven at $105^{\circ} \mathrm{C}$ for 1 hour followed by $80^{\circ} \mathrm{C}$ for 48 hours to determine their dry weight. The sound seedling index and root to shoot (R/S) ratio were subsequently calculated as follow:

sound seedling index = (stem diameter / plant height + root dry weight $/$

shoot dry weight)×whole dry weight

R/S ratio = root dry weight / shoot dry weight

\section{Analysis of root morphology}

Roots of five uniform plants from each treatment were randomly selected and washed with deionized water, then placed in a dedicated tray. The entangled roots were gently separated by hand and stretched flat. The root scanning was performed by using Imagery Scan Screen (Epson perfection V700 Photo, Indonesia). Total root length, root surface area, root diameter, root volume, root tips, and root forks were measured using image analysis through WinRHIZO Pro 2012a software.

\section{Measurement of $\mathrm{NO}_{3}{ }^{-}$content and $\mathrm{NO}_{3}{ }^{-}$uptake}

The $\mathrm{NO}_{3}{ }^{-}$content was measured by the colorimetric method utilizing salicylic acid according to Wang et al. (2018) and was calculated from the standard curve. Then $\mathrm{NO}_{3}{ }^{-}$uptake was calculated as the product of $\mathrm{NO}_{3}{ }^{-}$content and fresh weight.

\section{Measurement of NUE traits}

The $\mathrm{N}$ content was measured using the Kjeldahl method described by Bremner (1965). N accumulation (NA) was obtained as the product of $\mathrm{N}$ content and plant dry weight (mg N) (Lawlor 2002). N uptake efficiency (NUpE), N utlization efficiency (NUtE) 
and NUE of plants were calculated based on the the following formulas (Siddiqi and Glass 1981; Elliot and Laüchli 1985):

$\mathrm{NUpE}=\mathrm{N}$ accumulation / Root dry weight $(\mathrm{mg} \mathrm{N} / \mathrm{mg} \mathrm{DW})$

NUtE $=$ Total plant dry weight $/ \mathrm{N}$ contents $(\mathrm{mg} \mathrm{DW} / \mathrm{mg} \mathrm{N})$

NUE $=$ NUpE $\times$ NUtE $(\mathrm{mg} \mathrm{N} / \mathrm{mg} \mathrm{N})$

\section{Determination of leaf photosynthesis}

The first fully expanded true leaf from top was selected. The chlorophyll content was determined by $80 \%$ acetone extraction method according to Hussain et al. (2019). The net photosynthetic rate (Pn) and transpiration rate ( $\mathrm{Tr}$ ) were measured with a 6800 photosynthesizer apparatus from 9:00 am to 11:00 am on a sunny day.

\section{Total RNA extraction and gene expression analysis}

The root tips and leaves of grafted plants were selected to determine the relative expression of genes related to nitrate transporters (NRTs) and N metabolizing enzymes, respectively. Total RNA was extracted by using the Omega kit (Norcross, Georgia, USA) according to the manufacturer's instructions and treated with RNase-free DNase to remove contaminated DNA. First-strand cDNA was synthesized using M-MLV reverse transcriptase, and oligo-(dT) 18 was used as a primer following the manufacturer's recommendation [Accurate Biotechnology (Hunan) Co.,Ltd, Changsha, China]. Expression of the target genes was measured by quantitative real-time PCR (qRT-PCR). The watermelon NRT genes (Cla008783, Cla005079) and N metabolic genes (NR: Cla023145, NiR: Cla13062, GS1: Cla015195, GS2: Cla021675), and bottle gourd NRT genes (Lsi05G000610, Lsi03G001360) were selected as target genes. These genes were taken from the Cucurbitaceae Genome database (http://www.icugi.org/cgi-bin/ICuGl/genome/search.cgi). The specific primers (Table 1) were designed as described by Kong et al. (2014) using the Primer 5 Software. All the primers show high specificity for each gene. qRT-PCR was performed using the PerfectStart Green qPCR SuperMix kit (TransGen Biotech, Beijing, China) according to the protocols. PCR amplification included a min preincubation step at $94^{\circ} \mathrm{C}$, followed by 40 cycles of $94^{\circ} \mathrm{C}$ for $5 \mathrm{~s}, 60^{\circ} \mathrm{C}$ for $30 \mathrm{~s}$. The PCR products were quantified by the ABI Step One Plus real time PCR detection system and the data were analyzed by using $2^{-\Delta \Delta C t}$ method (Livak and Schmittgen. 2001). Self-grafted and rootstock-grafted watermelon seedlings under $9 \mathrm{mMN}$ treatment were used as control to calculate the relative gene expression. 
Table 1

List of primer sequences of watermelon and bottle gourd used for qRT-PCR analysis

\begin{tabular}{|llll|}
\hline Gene & Accession Number & Forward primer(5'-3') & Reverse primer(5'-3') \\
\hline Watermelon & & & \\
\hline NRT1.5 & Cla008783 & TGTTGGTGACAATGGTGATG & ATCACAGTCAAGGCAGCAAG \\
\hline NRT2.1 & Cla005079 & CAGATCATTGGGCTTGTGA & AAGGGAACCAGGGATAAAG \\
\hline NR & Cla023145 & GCACCGACAGCATTCTCA & CGGTATTCCTCCAGCATTT \\
\hline NiR & Cla13062 & CGATCTATACGAACACCCTC & CCAGCACATTGAACCCTA \\
\hline GS1 & Cla015195 & AGAGCACATTGCTGCCTATG & AGGCTCCTCTGTTTGCAACT \\
\hline GS2 & Cla021675 & GGAGCTTATCCAGGTCCTCA & AAGCCTTGTAGTGGGCATCT \\
\hline CIACT* & Cla007792 & CCATGTATGTTGCCATCCAG & GGATAGCATGGGGTAGAGCA \\
\hline Bottle gourd & & & \\
\hline NRT1.5 & Lsi05G000610 & TCAATGAACCGTGGTAGAAA & ATGGTGCAGAGCCAAATAG \\
\hline NRT2.1 & Lsi03G001360 & TAATTGGGCTTGTGAATGG & AAGGGAACCAGGGATAAAA \\
\hline LsiACT* & Lsi02G025660 & GGCAGTGGTTGTGAACATGT & CCCATGCTATCCTCCGTCTT \\
\hline * is reference gene (ACT) for qRT-PCR analysis & \\
\hline
\end{tabular}

\section{Statistical analysis}

A two-factorial ANOVA was performed to examine the effects of graft combination, $\mathrm{N}$ treatment, and their interaction on the plant samples. Significance levels were determined at ${ }^{*} P<0.05$, ${ }^{*} P<0.01$, and ${ }^{\star *} * \mathrm{P}<0.001$; ns denoted non-significant differences. Tukey HSD $(p<0.05)$ was used for the mean separation. Pearson's correlation analysis was used to analyze the correlation between NUE and other parameters of the self-grafted and rootstock-grafted watermelon seedlings under $9 \mathrm{mM}$ and $4 \mathrm{mMNO}_{3}{ }^{-} \mathrm{N}$ conditions, and the graphical presentation was carried out using OriginPro 2021. All analyses were conducted using SPSS 24.0 software package.

\section{Results}

Plant growth

For grafted plants, graft combination significantly affected the plant growth, and its interaction with $\mathrm{N}$ treatment significantly affected the plant height, shoot and whole dry weight (Table 2). The growth performance of bottle gourd rootstock-grafted $(\mathrm{Z} / \mathrm{J})$ plants were better than that of self-grafted (Z/Z) plants (Fig. 1a), correspondingly, the plant height, shoot, root, and whole dry weight, and sound seedling index of $Z / J$ plants were all significantly higher than those of $Z / Z$ plants regardless of the $N$ level (Table 2). Compared with $9 \mathrm{mMN}$ treatment, these growth parameters of Z/Z plants decreased slightly under $4 \mathrm{mMN}$ treatment, while increased in Z/J plants. For example, $4 \mathrm{mM} \mathrm{N}$ treatment reduced plant height, root, shoot, and whole dry weight, and sound seedling index of $Z / Z$ plants by $22 \%, 14 \%, 27 \%, 25 \%$ and $17 \%$, respectively, whereas increased the plant height, shoot and whole dry weight, and sound seedling index of Z/J plants by $22 \%, 28 \%, 23 \%$ and $2 \%$, respectively. 
Table 2

Effect of graft combination and $\mathrm{N}$ treatment on plant growth of the watermelon seedlings

\begin{tabular}{|c|c|c|c|c|c|c|c|c|c|c|c|}
\hline \multirow{2}{*}{$\begin{array}{l}\begin{array}{l}\text { Graft } \\
\text { combination }\end{array} \\
\mathrm{Z} / \mathrm{Z}\end{array}$} & \multirow{2}{*}{$\begin{array}{l}\mathrm{N} \\
\text { treatment } \\
9 \mathrm{mM}\end{array}$} & \multicolumn{2}{|c|}{$\begin{array}{l}\text { Plant height } \\
\text { (cm) }\end{array}$} & \multicolumn{2}{|c|}{$\begin{array}{l}\text { Root dry } \\
\text { weight } \\
\text { (g) }\end{array}$} & \multicolumn{2}{|c|}{$\begin{array}{l}\text { Shoot dry } \\
\text { weight } \\
\text { (g) }\end{array}$} & \multicolumn{2}{|c|}{$\begin{array}{l}\text { Whole plant } \\
\text { dry weight (g) }\end{array}$} & \multicolumn{2}{|c|}{ Sound seedling index } \\
\hline & & $\begin{array}{l}26.0 \\
\pm \\
0.36 \mathrm{c}\end{array}$ & $100 \%$ & $\begin{array}{l}0.14 \\
\pm \\
0.01 \mathrm{~b}\end{array}$ & $100 \%$ & $\begin{array}{l}0.71 \\
\pm \\
0.05 \mathrm{c}\end{array}$ & $100 \%$ & $\begin{array}{l}0.85 \\
\pm \\
0.06 \mathrm{c}\end{array}$ & $100 \%$ & $0.30 \pm 0.03 b$ & $100 \%$ \\
\hline & $4 \mathrm{mM}$ & $\begin{array}{l}20.4 \\
\pm \\
0.35 d\end{array}$ & $78 \%$ & $\begin{array}{l}0.12 \\
\pm \\
0.01 \mathrm{~b}\end{array}$ & $86 \%$ & $\begin{array}{l}0.52 \\
\pm \\
0.03 c\end{array}$ & $73 \%$ & $\begin{array}{l}0.64 \\
\pm \\
0.04 \mathrm{c}\end{array}$ & $75 \%$ & $0.25 \pm 0.03 b$ & $83 \%$ \\
\hline \multirow[t]{2}{*}{$\mathrm{Z} / \mathrm{J}$} & $9 \mathrm{mM}$ & $\begin{array}{l}38.8 \\
\pm \\
1.09 \mathrm{~b}\end{array}$ & $100 \%$ & $\begin{array}{l}0.35 \\
\pm \\
0.02 \mathrm{a}\end{array}$ & $100 \%$ & $\begin{array}{l}1.38 \\
\pm \\
0.10 \mathrm{~b}\end{array}$ & $100 \%$ & $\begin{array}{l}1.73 \\
\pm \\
0.12 \mathrm{~b}\end{array}$ & $100 \%$ & $0.60 \pm 0.03 a$ & $100 \%$ \\
\hline & $4 \mathrm{mM}$ & $\begin{array}{l}47.2 \\
\pm \\
0.50 \mathrm{a}\end{array}$ & $122 \%$ & $\begin{array}{l}0.34 \\
\pm \\
0.03 a\end{array}$ & $97 \%$ & $\begin{array}{l}1.76 \\
\pm \\
0.09 a\end{array}$ & $128 \%$ & $\begin{array}{l}2.12 \\
\pm \\
0.11 \mathrm{a}\end{array}$ & $123 \%$ & $0.61 \pm 0.04 a$ & $102 \%$ \\
\hline \multicolumn{12}{|c|}{ Analysis of variance } \\
\hline \multicolumn{2}{|c|}{$\mathrm{N}$ treatment $(\mathrm{N})$} & \multicolumn{2}{|l|}{ * } & \multicolumn{2}{|l|}{ ns } & \multicolumn{2}{|l|}{ ns } & \multicolumn{2}{|l|}{ ns } & \multicolumn{2}{|l|}{ ns } \\
\hline \multicolumn{2}{|c|}{ Graft combination (G) } & \multicolumn{2}{|l|}{$\star \star \star$} & \multicolumn{2}{|l|}{$* * *$} & \multicolumn{2}{|l|}{$\star * *$} & \multicolumn{2}{|l|}{$* \star \star$} & \multicolumn{2}{|l|}{$\star \star \star$} \\
\hline \multicolumn{2}{|l|}{$N \times G$} & \multicolumn{2}{|l|}{$\star \star \star ~$} & \multicolumn{2}{|l|}{ ns } & \multicolumn{2}{|l|}{ ** } & \multicolumn{2}{|l|}{$* *$} & \multicolumn{2}{|l|}{ ns } \\
\hline
\end{tabular}

For ungrafted plants, bottle gourd $(\mathrm{J})$ plants showed better growth performance than watermelon $(\mathrm{Z})$ plants under $9 \mathrm{mM}$ and 4 $m M N$ levels (Fig. 2a). Rootstock genotype significantly affected the plant growth (Fig. 3). The root and shoot dry weights, sound seedling index, and R/S ratio of $\mathrm{J}$ plants were about 2.0, 1.4, 3.1 and 1.4 times of Z plants under $9 \mathrm{mM} \mathrm{N}$ treatment, respectively, and 2.2, 1.6, 3.7, and 1.4 times under $4 \mathrm{mMN}$ treatment, respectively (Fig. 3).

Root morphology

For grafted plants, the root morphology traits were significantly affected by graft combination (Table 3). Between the two graft combinations, the root system of Z/J plants was larger than that of Z/Z plants (Fig. 1b), consistently, the total root length, root surface area, root volume, and root forks of Z/J plants were all significantly higher than those of Z/Z plants regardless of the $\mathrm{N}$ level (Table 3). Compared with $9 \mathrm{mMN}$ treatment, these parameters of Z/Z plants decreased slightly under $4 \mathrm{mMN}$ treatment, but increased in Z/J plants. For example, $4 \mathrm{mMN}$ treatment reduced the total root length, root surface area, root volume, and root forks of $\mathrm{Z} / \mathrm{Z}$ plants by $11 \%, 15 \%, 16 \%$, and $22 \%$, respectively, whereas increased the total root length and root forks of $Z / J$ plants by $4 \%$ and $11 \%$, respectively. 
Table 3

Effect of graft combination and $\mathrm{N}$ treatment on root morphology of the watermelon seedlings

\begin{tabular}{|c|c|c|c|c|c|c|c|c|c|}
\hline \multirow{2}{*}{$\begin{array}{l}\text { Graft } \\
\text { combination } \\
\mathrm{Z} / \mathrm{Z}\end{array}$} & \multirow{2}{*}{$\begin{array}{l}\mathbf{N} \\
\text { treatment } \\
9 \mathrm{mM}\end{array}$} & \multicolumn{2}{|c|}{$\begin{array}{l}\text { Total root length } \\
\text { (cm) }\end{array}$} & \multicolumn{2}{|c|}{$\begin{array}{l}\text { Root surface area } \\
\left(\mathrm{cm}^{2}\right)\end{array}$} & \multicolumn{2}{|l|}{$\begin{array}{l}\text { Root volume } \\
\left(\mathrm{cm}^{3}\right)\end{array}$} & \multicolumn{2}{|c|}{ Root forks } \\
\hline & & $\begin{array}{l}491 \pm \\
32.0 \mathrm{bc}\end{array}$ & $100 \%$ & $\begin{array}{l}133 \pm \\
6.97 b\end{array}$ & $100 \%$ & $\begin{array}{l}2.79 \pm \\
0.20 \mathrm{~b}\end{array}$ & $100 \%$ & $\begin{array}{l}3471 \pm \\
396 a b\end{array}$ & $100 \%$ \\
\hline & $4 \mathrm{mM}$ & $\begin{array}{l}438 \pm \\
41.2 \mathrm{c}\end{array}$ & $89 \%$ & $\begin{array}{l}113 \pm \\
12.0 \mathrm{~b}\end{array}$ & $85 \%$ & $\begin{array}{l}2.33 \pm \\
0.32 b\end{array}$ & $84 \%$ & $\begin{array}{l}2699 \pm \\
470 b\end{array}$ & $78 \%$ \\
\hline \multirow[t]{2}{*}{$\mathrm{Z} / \mathrm{J}$} & $9 \mathrm{mM}$ & $\begin{array}{l}680 \pm \\
53.7 a b\end{array}$ & $100 \%$ & $\begin{array}{l}266 \pm \\
16.7 a\end{array}$ & $100 \%$ & $\begin{array}{l}8.40 \pm \\
0.74 a\end{array}$ & $100 \%$ & $\begin{array}{l}3930 \pm \\
213 a b\end{array}$ & $100 \%$ \\
\hline & $4 \mathrm{mM}$ & $\begin{array}{l}704 \pm \\
58.7 a\end{array}$ & $104 \%$ & $\begin{array}{l}267 \pm \\
9.60 a\end{array}$ & $100 \%$ & $\begin{array}{l}8.30 \pm \\
0.86 a\end{array}$ & $99 \%$ & $\begin{array}{l}4371 \pm \\
232 a\end{array}$ & $111 \%$ \\
\hline \multicolumn{10}{|c|}{ Analysis of variance } \\
\hline \multicolumn{2}{|c|}{$\mathrm{N}$ treatment $(\mathrm{N})$} & \multicolumn{2}{|l|}{ ns } & \multicolumn{2}{|l|}{ ns } & \multicolumn{2}{|l|}{ ns } & \multicolumn{2}{|l|}{ ns } \\
\hline \multicolumn{2}{|c|}{ Graft combination (G) } & \multicolumn{2}{|l|}{$\star \star \star$} & \multicolumn{2}{|l|}{$\star \star \star \star ~$} & \multicolumn{2}{|l|}{$* * *$} & \multicolumn{2}{|l|}{$\star \star \star ~$} \\
\hline \multicolumn{2}{|l|}{$N \times G$} & \multicolumn{2}{|l|}{ ns } & \multicolumn{2}{|l|}{ ns } & \multicolumn{2}{|l|}{ ns } & \multicolumn{2}{|l|}{ ns } \\
\hline
\end{tabular}

For ungrafted plants, $\mathrm{N}$ treatment affected the total root length, while rootstock genotype and their interaction significantly affected all the root morphology traits (except that the interaction did not affect the root volume) (Fig. 4). The root system of $\mathrm{J}$ plants was significantly stronger than that of Z plants under $9 \mathrm{mM}$ and $4 \mathrm{mM} \mathrm{N}$ levels (Fig. 2b). The total root length, root surface area, root volume, and root forks of $\mathrm{J}$ plants were about 1.5, 1.7, 2.0, and 2.0 times of $\mathrm{Z}$ plants under $9 \mathrm{mMN}$ treatment, respectively, and 1.9, 2.1, 2.4, and 2.5 times under $4 \mathrm{mMN}$ treatment, respectively (Fig. 4).

$\mathrm{NO}_{3}{ }^{-}$content and $\mathrm{NO}_{3}{ }^{-}$uptake

For grafted plants, the total $\mathrm{NO}_{3}{ }^{-}$content was significantly affected by graft combination and $\mathrm{N}$ treatment (Fig. 5a), and the whole plant $\mathrm{NO}_{3}{ }^{-}$uptake was significantly affected by graft combination and its interaction with $\mathrm{N}$ treatment (Fig. $5 \mathrm{~b}$ ). The total $\mathrm{NO}_{3}{ }^{-}$content and $\mathrm{NO}_{3}{ }^{-}$uptake of $\mathrm{Z} / \mathrm{J}$ plants were all significantly higher than those of $\mathrm{Z} / \mathrm{Z}$ plants, especially in the roots. Compared with $9 \mathrm{mMN}$ treatment, $4 \mathrm{mMN}$ treatment reduced the total $\mathrm{NO}_{3}{ }^{-}$content and $\mathrm{NO}_{3}{ }^{-}$uptake of $\mathrm{Z} / \mathrm{Z}$ plants by $17 \%$ and $40 \%$, while the total $\mathrm{NO}_{3}{ }^{-}$content of $\mathrm{Z} / \mathrm{J}$ plants decreased by $9 \%$ and $\mathrm{NO}_{3}{ }^{-}$uptake increased by $14 \%$. Furthermore, the $\mathrm{NO}_{3}{ }^{-}$content and $\mathrm{NO}_{3}{ }^{-}$uptake in $\mathrm{Z} / \mathrm{J}$ plant roots decreased, but these values in leaves increased under $4 \mathrm{mMN}$ treatment.

For ungrafted plants, both total $\mathrm{NO}_{3}{ }^{-}$content and $\mathrm{NO}_{3}{ }^{-}$uptake were significantly affected by $\mathrm{N}$ treatment and rootstock genotype (Fig. 6). Compared with $9 \mathrm{mMN}$ treatment, $4 \mathrm{mMN}$ treatment reduced the $\mathrm{NO}_{3}{ }^{-}$content in $\mathrm{Z}$ plant roots and leaves by $32 \%$ and $25 \%$, and $\mathrm{NO}_{3}{ }^{-}$uptake by $38 \%$ and $42 \%$, respectively. However, $4 \mathrm{mM} \mathrm{N}$ treatment had no significant effect on $\mathrm{NO}_{3}{ }^{-}$content and $\mathrm{NO}_{3}{ }^{-}$uptake in $\mathrm{J}$ plant roots, while $\mathrm{NO}_{3}{ }^{-}$uptake in leaves decreased by $32 \%$ (Fig. 6). Furthermore, $\mathrm{Z}$ plants showed significantly higher $\mathrm{NO}_{3}{ }^{-}$uptake than that of $\mathrm{Z}$ plants regardless of the $\mathrm{N}$ level (Fig. 6b). For example, the whole plant $\mathrm{NO}_{3}{ }^{-}$uptake of $\mathrm{J}$ plants was about 1.4 times and 2.4 times higher than that of $\mathrm{Z}$ plants under $9 \mathrm{mM}$ and $4 \mathrm{mM} \mathrm{N}$ treatment, respectively.

Gene expression of nitrate transporters and N metabolizing enzymes 
Relative expression of nitrate transporters and N metabolizing enzymes genes was conducted in self-grafted and rootstockgrafted watermelon plants. According to the Cucurbitaceae Genome database, we identified two nitrate transport genes in watermelon and bottle gourd roots, respectively, and four $\mathrm{N}$ metabolizing enzymes genes in watermelon leaves (Table 1). The relative expression of these genes was significantly affected by $\mathrm{N}$ treatment, graft combination and their interaction (Fig. 7). The mRNA levels of NRT1.5 and NRT2.1 in the roots, and NR, NiR, GS1 and GS2 genes in the leaves of Z/J plants were upregulated significantly under $4 \mathrm{mMN}$ treatment compared to the $9 \mathrm{mMN}$ treatment. However, these genes in Z/Z plants did not change significantly under $4 \mathrm{mMN}$ treatment, except for the up-regulated expression of NiR and GS2 genes. Moreover, the gene expression of nitrate transporters and $\mathrm{N}$ metabolizing enzymes in rootstock-grafted watermelon seedlings was significantly higher than that in self-grafted plants. For example, under $4 \mathrm{mMN}$ treatment, the relative expression of $N R T 1.5$, NRT2.1, NiR, GS1 and GS2 genes in Z/J plants were 27.3, 2.9, 2.6, 1.8 and 2.5 times higher than that in Z/Z plants, respectively.

NA, NUpE, NUtE and NUE

The NA, NUpE, NUtE and NUE were all significantly affected by $N$ treatment, graft combination and their interaction (except that the $N$ treatment did not affect NUtE) (Figs. 8 and 9). Obviously, the NA in roots, stems and leaves of Z/J plants was remarkablely higher than that of $Z / Z$ plants, and increased significantly under $4 \mathrm{mMN}$ treatment, especially in leaves (Fig. 8). In addition, compared with $9 \mathrm{mMN}$ treatment, the NUpE, NUtE and NUE of Z/J plants were increased significantly under $4 \mathrm{mM}$ $\mathrm{N}$ treatment (Fig. 9). These NUE traits were all significantly higher than those of Z/Z plants, especially at $4 \mathrm{mMN}$ level. For example, the total NA, NUpE, NUtE and NUE of Z/J plants under $4 \mathrm{mMN}$ treatment were 3.8, 1.2, 3.3, and 3.8 times higher than that of Z/Z plants, respectively.

leaf photosynthesis

Graft combination significantly affected $\mathrm{Pn}, \mathrm{Tr}$ and chlorophyll content, and its interaction with $\mathrm{N}$ treatment significantly affected the Pn and chlorophyll content (Fig. 10). The Pn, Tr and chlorophyll content of Z/J plants were all higher than those of Z/Z plants regardless of the $\mathrm{N}$ level. Compared with $9 \mathrm{mMN}$ treatment, these parameters of Z/Z plants decreased slightly under $4 \mathrm{mMN}$ treatment but increased in Z/J plants. For example, $4 \mathrm{mMN}$ treatment reduced the $\mathrm{Pn}$, Tr and chlorophyll content of $\mathrm{Z} / \mathrm{Z}$ plants by $60 \%, 11 \%$, and $16 \%$, respectively, whereas increased by $35 \%, 15 \%$ and $27 \%$ in $\mathrm{Z} / \mathrm{J}$ plants, respectively.

Correlation analysis

Pearson's correlation analysis between the NUE and other parameters of the self-grafted and rootstock-grafted watermelon seedlings under $9 \mathrm{mM}$ and $4 \mathrm{mMNO}_{3}{ }^{-}-\mathrm{N}$ conditions was conducted (Fig. 11). The NUE was found to be positively correlated with the plant height, shoot dry weight, whole plant dry weight, NA, NUtE, Pn, Tr, and chlorophyll content; and all correlations between these parameters above were positive. NUtE was also positively correlated with the root dry weight, sound seedling index, total root length, root surface area, root volume, and whole plant $\mathrm{NO}_{3}{ }^{-}$uptake; meantime, all these parameters were positively correlated with each other, and they were also positively correlated with the plant height, shoot dry weight, whole plant dry weight, NA and $\operatorname{Tr}$ (except that RV has no correlation with $\mathrm{PH}$ ). In addition, the whole plant $\mathrm{NO}_{3}{ }^{-}$uptake was also positively correlated with $\mathrm{Pn}$ and chlorophyll content. The NUpE was positively correlated with the relative expression of NRT1.5, NRT2.1 and GS1 genes, and the relative expression of NRT1.5 and NRT2.1 genes, as well as the NiR, GS1 and GS2 genes were all positively correlated with each other.

\section{Discussion}

\section{Bottle gourd rootstock grafting increases watermelon growth performance under low-nitrate condition}

Appropriate rootstock grafting can promote plant growth and improve plant tolerance to nutrient deficiency (Huang et al. 2013, 2016). In this study, the growth performance of bottle gourd rootstock-grafted watermelon seedlings was obviously better than that of self-grafted seedlings, especially under low-nitrate condition (Fig. 1a, Table 2). The analysis of variance showed that 
graft combination significantly affected plant growth, and the growth performance of ungrafted bottle gourd seedlings was also significantly better than that of ungrafted watermelon seedlings, regardless of the $\mathrm{N}$ level (Table 2, Figs. 2a and 3). These results demonstrated that bottle gourd rootstock grafting is an effective approach to improve watermelon growth performance under low N, and its efficiency is dependent on the rootstock genotype. Similar results have been reported in grafted cucumber (Liang et al. 2021). Nevertheless, Huang et al. (2016) reported that the bottle gourd rootstock grafting could not improve the watermelon performance under low Mg stress, while the improving effects can be found when grafted with pumpkin rootstock. This difference implies that suitable rootstocks should be carefully selected according to different nutrient deficiency environments. Moreover, we found that under $4 \mathrm{mM}$ low-nitrate treatment, the growth of self-grafted watermelon plants slightly inhibited, but increased in rootstock-grafted plants relative to the $9 \mathrm{mM}$ nitrate treatment. We suggest that bottle gourd rootstock grafting is expected to reduce $\mathrm{N}$ fertilizer application without compromising the plant growth of watermelon seedlings.

\section{Bottle gourd rootstock-grafted watermelon plants have better root advantages in response to low-nitrate treatment}

Root system plays a crucial role in adapting to changes in $\mathrm{N}$ availabilities (Rellán-Álvarez et al. 2016), and genetic components determine the fundamental morphology of plant roots (Pacheco-Villalobos and Hardtke 2012). Similarly, the results of our experiment showed that bottle gourd rootstock-grafted watermelon seedlings had larger root system than self-grafted seedlings, regardless of the $\mathrm{N}$ level (Fig. 1b, Table 3). The analysis of variance showed that graft combination significantly affected root morphological traits, and these parameters in ungrafted bottle gourd seedlings were significantly higher than those of ungrafted watermelon seedlings (Table 3, Figs. $2 \mathrm{~b}$ and 4). These results indicated that rootstock-grafted watermelon plants had greater root advantage than self-grafted plants, which benefited from the genetic characteristics of bottle gourd rootstock. This may partly explain the superior growth of rootstock-grafted watermelon plants, since root morphological characteristics determine a plant's ability to acquire $\mathrm{N}$ which directly affecting the growth and development of plants (Jiang et al. 2017). The results of correlation analysis also showed that the growth parameters (including sound seedling index, root dry weight and whole dry weight) were positively correlated with root morphological traits (including total root length, root surface area, and root volume) (Fig. 11).

In addition, numerous studies showed that plant roots can signal the plant to alter the root system in response to various levels of $\mathrm{N}$ availability, so as to meet their own demand for $\mathrm{N}$ fertilizer (Pacheco-Villalobos and Hardtke 2012; lqbal et al. 2020). In present study, the results showed that at $4 \mathrm{mM}$ low-nitrate level, the total root length and root forks of bottle gourd rootstock-grafted seedlings and the total root length of ungrafted bottle gourd plants were increased, whereas these parameters of self-grafted seedlings decreased slightly (Table 3, Fig. 4a). The results showed that the bottle gourd rootstock could better adapt to low $\mathrm{N}$ through morphological variation.

$\mathrm{NO}_{3}{ }^{-}$uptake and transport of watermelon were improved by grafting onto bottle gourd rootstock under low-nitrate condition

Nitrate nitrogen $\left(\mathrm{NO}_{3}{ }^{-}-\mathrm{N}\right)$ is one of the principal forms of available $\mathrm{N}$ in plants that determines the level of growth and development of plants. In this study, we found that regardless of the $\mathrm{N}$ level, the total $\mathrm{NO}_{3}{ }^{-}$content and $\mathrm{NO}_{3}{ }^{-}$uptake of rootstock-grafted watermelon seedlings were significantly higher than those of self-grafted seedlings (Fig. 5 ), and the $\mathrm{NO}_{3}{ }^{-}$ uptake of ungrafted bottle gourd plants was also higher than that of ungrafted watermelon plants (Fig. 6), indicating that grafting with bottle gourd rootstock could improve the $\mathrm{NO}_{3}{ }^{-}$uptake of watermelon seedlings. Yang et al. (2013) also reported that bottle gourd rootstock-grafting can promote $\mathrm{NO}_{3}{ }^{-}$uptake in $\mathrm{NaCl}$-stressed watermelon leaves. Genotypic variation of nitrogen utilization efficiency in oilseed rape showed that $\mathrm{N}$-efficient genotype exhibited higher root $\mathrm{N}$ uptake than $\mathrm{N}$-inefficient genotype (He et al. 2021). Furthermore, compared with $9 \mathrm{mM}$ nitrate treatment, $4 \mathrm{mM}$ low-nitrate treatment significantly reduced the total $\mathrm{NO}_{3}{ }^{-}$content and $\mathrm{NO}_{3}{ }^{-}$uptake of self-grafted plants, whereas increased the total $\mathrm{NO}_{3}{ }^{-}$uptake of rootstockgrafted plants, especially increased the $\mathrm{NO}_{3}{ }^{-}$content and $\mathrm{NO}_{3}{ }^{-}$uptake in the leaves of rootstock-grafted plants (Fig. 5). This result shows that bottle gourd rootstock grafting can improve the $\mathrm{NO}_{3}{ }^{-}$uptake and root-to-shoot transport of watermelon

Page $10 / 24$ 
seedlings under low-nitrate condition, which is in line with the results of Savvas et al. (2017), who found that nutrient uptake and translocation to the shoot were often improved in favourable grafting combinations. Correlation analysis showed that whole plant $\mathrm{NO}_{3}{ }^{-}$uptake was positively correlated with certain root morphological traits (Fig. 11), implying that the vigorous root systems of bottle gourd rootstock play an essential role in promoting the $\mathrm{NO}_{3}{ }^{-}$absorption and translocation of grafted watermelon seedlings. Martínez-Ballesta et al. (2010) reported that owing to the vigor of rootstocks, grafted plants usually show an increased uptake of water and minerals compared with self-rooted plants under favorable growth conditions. In addition, the total $\mathrm{NO}_{3}{ }^{-}$uptake of rootstock-grafted watermelon seedlings increased under $4 \mathrm{mM}$ low-nitrate treatment but decreased in ungrafted bottle gourd seedlings, especially in the leaves (Figs. 5b and 6b). This may be attributed to the scion/rootstock interaction, which can be regulated by root-shoot-root long-distance signaling (Sasaki et al. 2014).

It is well known that the absorption of $\mathrm{NO}_{3}{ }^{-}$by plants is carried out through nitrate transporters (NRTs) located on the cell membrane of plant root epidermis and cortex. In superior plants, nitrate transporters include HATS and LATS that operate at low concentrations of $\mathrm{NO}_{3}{ }^{-} \mathrm{N}(<1.0 \mathrm{mM})$ and above $1.0 \mathrm{mM}$, respectively, which are encoded by the NRT2 and NRT1 gene families, respectively (Bucher et al. 2014). A large number of studies have shown that NRTs play an important role in $\mathrm{NO}_{3}{ }^{-}$ uptake and transport in many plants. However, these studies were mainly carried out on Arabidopsis (Zou et al. 2019; Jacquot et al. 2020) and field crops such as rice (Chen and Ma 2015), rape (Tong et al. 2020) and barley (Guo et al. 2020); the expression pattern and function of NRTs in vegetable plants are still less studied. Li et al. (2017) reported that the AtNRT1.5 is expressed in the peri sheath of Arabidopsis root and is responsible for loading $\mathrm{NO}_{3}{ }^{-}$into xylem in root system. AtNRT2.1 mediates root high-affinity $\mathrm{NO}_{3}{ }^{-}$influx of Arabidopsis roots and affects the transport of nitrate nitrogen to leaves ( $\mathrm{Li}$ et al. 2007). In addition, NRT2 can regulate lateral root initiation in nitrate signaling pathway. In addition, NRT2.1 plays a direct stimulating role in the specific step of lateral root development, and can coordinate root development and external $\mathrm{NO}_{3}{ }^{-}$ availability (Remans et al. 2006). In this study, the response of NRT gene expression in roots of self-grafted and rootstockgrafted watermelon plants to low nitrogen was quite different, the expression of NRT1.5 and NRT2.1 genes in roots of rootstock-grafted plants was significantly up-regulated under low-nitrate treatment, but there was no change in self-grafted plants (Fig. 7a and b). The bottle gourd rootstock-grafted plants had a higher ability to absorb $\mathrm{NO}_{3}{ }^{-}$than self-grafted plants. Therefore, the different expression levels of $\mathrm{NO}_{3}{ }^{-}$transporter gene may be part of the reason for the differences of $\mathrm{NO}_{3}{ }^{-}$ absorption between self-grafted and rootstock-grafted watermelon plants, the NRT genes (NRT1.5 and NRT2.1) may related in the higher $\mathrm{NO}_{3}{ }^{-}$uptake by rootstock-grafted plant roots. However, other $\mathrm{NO}_{3}{ }^{-}$transporter genes associated with high uptake of $\mathrm{NO}_{3}{ }^{-}$in rootstock-grafted plant roots need to be further studied.

\section{N metabolism ability of watermelon was enhanced by grafting onto bottle gourd rootstock under low-nitrate condition}

$\mathrm{NO}_{3}{ }^{-} \mathrm{N}$ is absorbed into cells by plant roots and assimilated into amino acids and proteins through the reduction of a series of enzymes, such as NR, NiR, GS, and GOGAT (Xu et al. 2012). Among these enzymes, NR and GS are the rate-limiting enzymes of $\mathrm{NO}_{3}{ }^{-}-\mathrm{N}$ assimilation and play a crucial role in plants response to $\mathrm{N}$ deficiency (Kaur et al. 2015). NR and NiR convert nitrate to ammonium through the sequential reductive enzymatic action, and then the ammonium derived from nitrate reduction is further assimilated via the GS/GOGAT cycle. GS1 and GS2 are two isozymes of GS in cytoplasm and chloroplast, respectively. Zhang et al. (2017) reported that the NUE of cucumber could be enhanced by regulating the relative activity or expression of GS1/GS2. Yang et al. (2013) found that the increased N uptake and assimilation of rootstock-grafted watermelon in salinity stress is related to the enhancement of NR enzyme activity. Our previous research also showed that rootstock grafting can promote $\mathrm{N}$ metabolism of cucumber by increasing the activity of $\mathrm{N}$ metabolism enzymes (Liang et al. 2021). However, previous studies mainly focused on the physiological changes of enzyme activity, while little is known about the transcriptional expression of these enzyme related genes, especially in grafted plants. Therefore, the expression of $\mathrm{N}$ metabolizing enzyme genes in grafted watermelon leaves was studied. The results showed that NR, NiR, GS1 and GS2 genes in the leaves of bottle gourd rootstock-grafted plants were significantly up-regulated under $4 \mathrm{mM}$ low-nitrate treatment relative to the $9 \mathrm{mM}$ nitrate treatment, and were generally higher than those of self-grafted plants (Fig. 7c-f). The results proved that 
under low-nitrate condition, bottle gourd rootstock grafting could enhance $\mathrm{N}$ metabolism ability of watermelon seedlings by regulating the transcriptional expression of $\mathrm{N}$ metabolizing enzyme genes. The correlation analysis showed that the relative expression of NRT1.5 and NRT2.1 genes, as well as the NiR, GS1 and GS2 genes were all positively correlated with each other (Fig. 11), implying that the $\mathrm{NO}_{3}{ }^{-}$metabolism in rootstock-grafted watermelon leaves was closely related to its absorption by roots and root-to-shoot transport.

\section{Bottle gourd rootstock grafted plants have higher NUE and photosynthetic capacity under low-nitrate condition}

After assimilation and metabolism, $\mathrm{NO}_{3}{ }^{-}$is gradually become incorporated into organic compounds, such as amino acids, proteins, and other $\mathrm{N}$ compounds necessary for plant growth and development (Pratelli and Pilot 2014). Consistent with the change of plant $\mathrm{NO}_{3}{ }^{-}$uptake, the $\mathrm{N}$ accumulation in roots, stems and leaves of bottle gourd rootstock-grafted plants was significantly higher than that of self-grafted plants, and increased under low-nitrate treatment, especially in the leaves (Fig. 8). The results indicated that watermelon grafted onto bottle gourd rootstock can not only absorb more N, but also transfer more $\mathrm{N}$ to leaves, so as to maintain high $\mathrm{N}$ accumulation and finally promote growth, which is agree with the view of Savvas et al. (2017). The correlation analysis also showed that there was a significant positive correlation between $\mathrm{NO}_{3}{ }^{-}$uptake, $\mathrm{N}$ accumulation and plant biomass (Fig. 11).

The ability of plants to absorb and utilization nitrogen can be evaluated according to two representative indexes: NUpE and NUtE. The NUpE and NUtE further jointly determine the overall NUE, and this role is influenced by the N supply (Garnett et al. 2015). Increasing the NUE is important to maintain a high productivity under low N supply (Xu et al. 2012). In general, plants have evolved a variety of mechanisms to increase $N$ use (Bascuñán-Godoy et al. 2018). Efficient genotype have specific physiological mechanisms that enable them to absorb sufficient $\mathrm{N}$ and/or use the absorbed $\mathrm{N}$ more effectively. Similar results were discovered in our present study, which showed that the NUpE, NUtE, and NUE of bottle gourd rootstock-grafted plants were significantly higher than those of self-grafted plants (except of the non-significant in NUpE between self-grafted and rootstock-grafted plants under control treatment), regardless of the $\mathrm{N}$ level (Fig. 9), indicating that bottle gourd rootstock grafting is a very useful way to promote the NUE of watermelon seedlings though improving the NUpE and NUtE. Similar results were reported by previous studies (Yang et al. 2013; Nawaz et al. 2017; Sallaku et al. 2019). Furthermore, we found that $4 \mathrm{mM}$ low-nitrate treatment remarkably increased the NUE traits of bottle gourd rootstock-grafted plants compared with control treatment, (Fig. 9). These results suggest the $4 \mathrm{mM}$ nitrate concentrations in this experiment provided an appropriate level of $\mathrm{N}$ fertilization for bottle gourd rootstock-grafted watermelon seedlings, and appropriate $\mathrm{N}$ deficiency supply will not cause stress inhibition to the growth of watermelon seedlings, but may help to improve the NUE and promote the growth of watermelon seedlings (Chen et al. 2020).

In addition, photosynthesis is the main source of plant organic matter and participates in the synthesis of $\mathrm{N}$-containing substances in chloroplasts. In turn, photosynthesis is also very sensitive to the change of $N$ availability (Qin et al. 2018; Xu et al. 2015), because $57 \%$ of the $N$ in the leaves is located in the chloroplasts, which is used to synthesize photosynthetic components and related enzymes (Xu et al. 2012). Therefore, there is a close coupling relationship exists between photosynthesis and $\mathrm{N}$ metabolism. In this study, we found that the Pn, Tr and chlorophyll contents of rootstock-grafted plants were all higher than those of self-grafted plants, and increased under $4 \mathrm{mM}$ low-nitrate treatment, but decreased slightly in selfgrafted plants (Fig. 10). The correlation analysis showed that the photosynthetic characteristics were positively correlated with $\mathrm{N}$ accumulation and NUtE (Fig. 11). The results indicated that watermelon grafted onto gourd rootstock can accumulate more $\mathrm{N}$ to enhance photosynthetic capacity. Furthermore, photosynthesis is related to the dry matter accumulation of plants, which is the basis for increasing crop growth, productivity, and NUE (Huang et al. 2016; lqbal et al. 2020). The correlation analysis in this study proved that the photosynthetic characteristics were significant positive correlated with NUE and plant biomass (including plant height, shoot dry weight and whole dry weight) (Fig. 11).

Overall, correlation analysis showed that there were inextricably linked positive correlations among plant growth, root morphology traits, plant $\mathrm{NO}_{3}{ }^{-}$uptake, photosynthetic characteristics, NUtE and NUE (Fig. 11). Combined with the changes of

Page $12 / 24$ 
the above parameters in the text, we infer that grafting with bottle gourd rootstock may increase plant growth and NUE of watermelon seedlings by making better use of their developed roots and enhancing $\mathrm{N}$ metabolism potential and photosynthetic capacity to promote $\mathrm{NO}_{3}{ }^{-}$absorption, assimilation and metabolism. The significant positive correlation between the gene expression of nitrate transporters and $\mathrm{N}$ metabolizing enzymes further revealed that the enhanced $\mathrm{NO}_{3}{ }^{-}$ uptake and $\mathrm{N}$ metabolism of rootstock-grafted plants were regulated at the transcriptional level. The results of this study provide key insights into how NUE could be improved under reduced $\mathrm{N}$ fertilizer application without compromising plant growth in the context of watermelon seedlings growth. As for mature plants, could be further studied in later experiments. Moreover, most previous studies have showed that there is chemical signaling from the root to the shoot, which plays an important role in regulating a plant's morphology and physiology (Tsutsui and otaguchi 2017). Therefore, it is necessary to further study the signal regulation pathway of grafting to promote watermelon plant growth and nitrogen use efficiency.

\section{Conclusions}

In conclusion, bottle gourd rootstock grafting can effectively promote the plant growth and NUE of watermelon seedlings, and the rootstock characteristics played a crucial role. The physiological mechanism of the improved performance of grafted watermelon under low $\mathrm{N}$ is related to the vigorous root systems and improved $\mathrm{NO}_{3}{ }^{-}$absorption capacity benefited from rootstock, and enhanced N metabolism potential in scion leaves. Significant up-regulation of nitrate transporter genes (NRT1.5 and NRT2.1) and $N$ metabolizing enzyme genes (NR, NiR, GS1 and GS2) may be partially responsible for the improvements in $\mathrm{NO}_{3}{ }^{-}$uptake and metabolism of rootstock-grafted watermelon seedlings under low-nitrate treatment. Furthermore, rootstock grafting very likely to decrease the risk of yield loss of watermelon induced by inappropriate $\mathrm{N}$ supply, reduce inorganic $\mathrm{N}$ fertilizer waste, increase the efficiency with which resources are used, and reduce the cost of production without sacrificing plant growth. The 'Jingxinzhen No.1' bottle gourd could be considered as a promising rootstock for plant grafting under low $\mathrm{N}$ conditions.

\section{Declarations}

Acknowledgments This work was supported by the Basic Research Program of Natural Science in Shaanxi Province (2021JQ142), the Shaanxi Innovative Research Team (2021TD-34), Shaanxi Agricultural Science and Technology Innovation Project (NYKJ-2021-YL(XN)04), and Xi'an Science and Technology Plan (21NYYF0031).

\section{Funding}

This work was supported by the Basic Research Program of Natural Science in Shaanxi Province (2021JQ-142), the Shaanxi Innovative Research Team (2021TD-34), Shaanxi Agricultural Science and Technology Innovation Project (NYKJ2021-YL(XN)04), and Xi'an Science and Technology Plan (21NYYF0031).

\section{Competing Interests}

The authors have no relevant financial or non-financial interests to disclose.

\section{Ethics approval}

This research did not involve human participants or animals.

\section{Author Contributions}

All authors contributed to the study conception and design. Material preparation and data collection were performed by Xiaoling Chen, Peijin Guo, Zhiyu Wang and Wenwen He. Jiayi Liang and Guohu Li analyzed the data. Xiaoling Chen wrote this manuscript. Ai zhen designed the experiment and revised this manuscript. All authors read and approved the final manuscript.

\section{Data Availability}

Page $13 / 24$ 
The datasets generated during and analysed during the current study are available from the corresponding author on reasonable request.

\section{References}

1. Albacete A, Martínez-Andújar C, Martínez-Pérez A, Thompson AJ, Dodd IC, Pérez-Alfocea F (2015) Unravelling rootstock × scion interactions to improve food security. J Exp Bot 66:2211-2226

2. Bascuñán-Godoy L, Sanhueza C, Pinto K, Cifuentes L, Reguera M, Briones V, Zurita-Silva A, Álvarez R, Morales A, Silva $H$ (2018) Nitrogen physiology of contrasting genotypes of Chenopodium quinoa Willd. (Amaranthaceae) Sci Rep 8:17524

3. Bremner JM, Black CA, Evans DD, White IL, Ensminger LE, Clark FE (1965) Total nitrogen. Methods of soil analysis. American Society of Agronomy, Wisconsin, pp 1149-1178

4. Bucher CA, Santos LA, de Matos Nogueira E, Rangel RP, de Souza SR, Fernandes MS (2014) The transcription of nitrate transporters in upland rice varieties with contrasting nitrate-uptake kinetics. J Plant Nutr Soil Sci 177:395-403

5. Chen ZC, Ma JF (2015) Improving nitrogen use efficiency in rice through enhancing root nitrate uptake mediated by a nitrate transporter, NRT1.1B. J Genet Genomics 42:463-465

6. Chen HH, Jia YM, Xu H, Wang YW, Zhou Y, Huang ZR, Yang LT, Li Y, Chen L-S, Guo JX (2020) Ammonium nutrition inhibits plant growth and nitrogen uptake in citrus seedlings. Sci Hortic 272:109526

7. Colla G, Rouphael Y, Mirabelli C, Cardarelli M (2011) Nitrogen-use efficiency traits of mini-watermelon in response to grafting and nitrogen fertilization doses. J Plant Nutr Soil Sci 174:933-941

8. De Oliveira MMT, Lu SH, Zurgil U, Raveh E, Tel-Zur N (2021) Grafting in Hylocereus (Cactaceae) as a tool for strengthening tolerance to high temperature stress. Plant Physiol Biochem 160:94-105

9. Elliott GC, Läuchli A (1985) Phosphorus efficiency and phosphate-iron interaction in maize. Agron J 77:399-403

10. Garnett T, Plett D, Conn V, Conn S, Rabie H, Rafalski JA, Dhugga K, Tester MA, Kaiser BN (2015) Variation for N uptake system in maize: genotypic response to $\mathrm{N}$ supply. Front Plant Sci 6:936

11. Gomes LDL, Ferreira ML, Kanashiro S, Tavares AR (2021) Nitrogen uptake by ornamental bromeliad: leaf and root efficiency. Plant Soil 466:293-302

12. Guo BJ, Li Y, Wang S, Li DF, Lv C, Xu RG (2020) Characterization of the nitrate transporter gene family and functional identification of HvNRT2. 1 in barley (Hordeum vulgare L.). PLoS ONE 15:e0232056

13. Hassell RL, Memmott F, Liere DG (2008) Grafting methods for watermelon production. HortScience 43:1677-1679

14. He HY, Xie YY, Zhao AY, Hu WC, Guo X, Miller AJ, Wu XM, Chen BY, Zhang R, Tian H, Gao YJ (2021) Genotypic variation in nitrogen utilization efficiency in oilseed rape is related to the coordination of leaf senescence and root $\mathrm{N}$ uptake during reproductive stage. Plant Soil 463:291-306

15. Huang Y, Jiao YY, Nawaz MA, Chen C, Liu L, Lu Z, Kong QS, Cheng F, Bie ZL (2016) Improving magnesium uptake, photosynthesis and antioxidant enzyme activities of watermelon by grafting onto pumpkin rootstock under low magnesium. Plant Soil 409:229-246

16. Huang Y, Li J, Hua B, Liu ZX, Fan ML, Bie ZL (2013) Grafting onto different rootstocks as a means to improve watermelon tolerance to low potassium stress. Sci Hort 149:80-85

17. Hussain S, lqbal N, Brestic M, Raza MA, Pang T, Langham DR, Safdar ME, Ahmed S, Wen BX, Gao Y, Liu WG, Yang WY (2019) Changes in morphology, chlorophyll fluorescence performance and Rubisco activity of soybean in response to foliar application of ionic titanium under normal light and shade environment. Sci Total Environ 658:626-637

18. Iqbal A, Dong Q, Alamzeb M, Wang XR, Gui HP, Zhang HH, Pang NC, Zhang XL, Song MZ (2019) Untangling the molecular mechanisms and functions of nitrate to improve nitrogen use efficiency. J Sci Food Agric 100:904-914

19. Iqbal A, Dong Q, Wang Z, Wang XR, Gui HP, Zhang HH, Pang NC, Zhang XL, Song MZ (2020) Growth and nitrogen metabolism are associated with nitrogen-use efficiency in cotton genotypes. Plant Physiol Biochem 149:61-74 
20. Jacquot A, Chaput V, Mauries A, Li Z, Tillard P, Fizames C, Bonillo P, Bellegarde F, Laugier E, Santoni V, Hem S, Martin A, Gojon A, Schulze W, Lejay L (2020) NRT2.1 C-terminus phosphorylation prevents root high affinity nitrate uptake activity in Arabidopsis thaliana. New Phytol 228:1038-1054

21. Jiang SY, Sun JY, Tian ZW, Hu H, Michel EJS, Gao JW, Jiang D, Cao WX, Dai TB (2017) Root extension and nitrate transporter up-regulation induced by nitrogen deficiency improves nitrogen status and plant growth at the seedling stage of winter wheat (Triticum aestivum L.). Environ Exp Bot 141:28-40

22. Kaur G, Asthir B, Bains NS, Farooq M (2015) Nitrogen nutrition, its assimilation and remobilization in diverse wheat genotypes. Int J Agric Biol 17:531-538

23. Kong QS, Yuan JX, GaoLY ZhaoS, Jiang W, Huang Y, Bie ZL (2014) Identification of suitable reference genes for gene expression normalization in qRT-PCR analysis in watermelon. PLoS ONE 9:e90612

24. Krapp A (2015) Plant nitrogen assimilation and its regulation: a complex puzzle with missing pieces. Curr Opin Plant Biol 25:115-122

25. Lawlor DW (2002) Carbon and nitrogen assimilation in relation to yield: mechanisms are the key to understanding production systems. J Exp Bot 53:773-787

26. Li WB, Wang Y, Okamoto M, Crawford NM, Siddiqi MY, Glass ADM (2007) Dissection of the AtNRT2.1:AtNRT2.2 inducible high-affinity nitrate transporter gene cluster. Plant Physiol 143:425-433

27. Li H, Yu M, Du XQ, Wang ZF, Wu WH, Quintero FJ, Jin X-H, Li HD, Wang Y (2017) NRT1.5/NPF7.3 functions as a protoncoupled $\mathrm{H}^{+} / \mathrm{K}^{+}$antiporter for $\mathrm{K}^{+}$loading into the xylem in Arabidopsis. Plant Cell 29:2016-2026

28. Li WM, Yan MK, Hu BY, Priyadarshani SVGN, Hou ZM, Ojolo SP, Xiong JJ, Zhao HM, Qin Y (2018) Characterization and the expression analysis of nitrate transporter (NRT) gene family in pineapple. Trop Plant Biol 11:177-191

29. Liang JY, Chen XL, Guo PJ, Ren HZ, Xie ZL, Zhang Z, Zhen A (2021) Grafting improves nitrogen-use efficiency by regulating the nitrogen uptake and metabolism under low-nitrate conditions in cucumber. Sci Hortic 289:110454

30. Livak KJ, Schmittgen TD (2001) Analysis of relative gene expression data using real-time quantitative PCR and the $2^{-}$ $\Delta \Delta \mathrm{CT}$ method. Methods 25:402-408

31. Lo'ay AA, Abo EL (2021) Performance of 'Flame seedless' grapevines grown on different rootstocks in response to soil salinity stress. Sci Hortic 275:109704

32. Luo LD, Zheng Y, Gao ZA, Chen Q, Kong XX, Yang YP (2020) Grafting improves drought stress memory by increasing the P5CS1 gene expression in Brassica rapa. Plant Soil 452:61-72

33. Martínez-Ballesta MC, Muries B, Mota-Cadenas C, Carvajal M (2010) Physiological aspects of rootstock-scion interactions. Sci Hortic 127:112-118

34. Nawaz MA, Wang LM, Jiao YY, Chen C, Zhao L, Mei MJ, Yu YL, Bie ZL, Huang Y (2017) Pumpkin rootstock improves nitrogen use efficiency of watermelon scion by enhancing nutrient uptake, cytokinin content, and expression of nitrate reductase genes. Plant Growth Regul 82:233-246

35. Özmen S, Kanber R, Sarı N, Ünlü M (2015) The effects of deficit irrigation on nitrogen consumption, yield, and quality in drip irrigated grafted and ungrafted watermelon. J Integr Agric 14:966-976

36. Pacheco-Villalobos D, Hardtke CS (2012) Natural genetic variation of root system architecture from Arabidopsis to Brachypodium: towards adaptive value. Phil Trans R Soc B-Biol Sci 367:1552-1558

37. Pratelli R, Pilot G (2014) Regulation of amino acid metabolic enzymes and transporters in plants. J Exp Bot 65:55355556

38. Qiao YJ, Yin LN, Wang BM, Ke QB, Deng XP, Wang SW (2019) Melatonin promotes plant growth by increasing nitrogen uptake and assimilation under nitrogen deficient condition in winter wheat. Plant Physiol Biochem 139:342-349

39. Qin F, Liu G, Huang GQ, Dong TF, Liao YM, Xu X (2018) Zinc application alleviates the adverse effects of lead stress more in female Morus alba than in males. Environ Exp Bot 146:68-76 
40. Rahman M, Islam T, Jett L, Kotcon J (2021) Biocontrol agent, biofumigation, and grafting with resistant rootstock suppress soil-borne disease and improve yield of tomato in West Virginia. Crop Prot 145:105630

41. Rellán-Álvarez R, Lobet G, Dinneny JR (2016) Environmental control of root system biology. Annu Rev Plant Biol 67:619642

42. Remans T, Nacry P, Pervent M, Girin T, Tillard P, Lepetit M, Gojon A (2006) A central role for the nitrate transporter NRT2.1 in the integrated morphological and physiological responses of the root system to nitrogen limitation in Arabidopsis. Plant Physiol 140:909-921

43. Sallaku G, Sandén H, Babaj I, Kaciu S, Balliu A, Rewald B (2019) Specific nutrient absorption rates of transplanted cucumber seedlings are highly related to RGR and influenced by grafting method, AMF inoculation and salinity. Sci Hortic 243:177-188

44. Sasaki T, Suzaki T, Soyano T, Kojima M, Sakakibara H, Kawaguchi M (2014) Shoot-derived cytokinins systemically regulate root nodulation. Nat Commun 5:4983

45. Savvas D, Öztekin GB, Tepecik M, Ropokis A, Tüzel Y, Ntatsi G, Schwarz D (2017) Impact of grafting and rootstock on nutrient-to-water uptake ratios during the first month after planting of hydroponically grown tomato. $J$ Horticult Sci Biotechnol 92:294-302

46. Siddiqi MY, Glass ADM (1981) Utilization index: a modified approach to the estimation and comparison of nutrient utilization efficiency in plants. J Plant Nutr 4:289-302

47. Tong JF, Walk TC, Han PP, Chen LY, Shen XJ, Li YS, Gu CM, Xie LH, Hu XJ, Liao X, Qin L (2020) Genome-wide identification and analysis of high-affinity nitrate transporter 2 (NRT2) family genes in rapeseed (Brassica napus L.) and their responses to various stresses. BMC Plant Biol 20:464

48. Wang Y-Y, Cheng Y-H, Chen K-E, Tsay Y-F (2018) Nitrate transport, signaling, and use efficiency. Annu Rev Plant Biol 69:85-122

49. Xu GH, Fan XR, Miller AJ (2012) Plant nitrogen assimilation and use efficiency. Annu Rev Plant Biol 63:153-182

50. Xu X, Li YX, Wang BX, Hu JY, Liao YM (2015) Salt stress induced sex-related spatial heterogeneity of gas exchange rates over the leaf surface in Populus cathayana Rehd. Acta Physiol Plant 37:1709

51. Yang YJ, Lu XM, Yan B, Li B, Sun J, Guo SR, Tezuka T (2013) Bottle gourd rootstock-grafting affects nitrogen metabolism in $\mathrm{NaCl}$-stressed watermelon leaves and enhances short-term salt tolerance. J Plant Physiol 170:653-661

52. Yuan LY, Zhu SD, Li SH, Shu S, Sun J, Guo SR (2014) 24-Epibrassinolide regulates carbohydrate metabolism and increases polyamine content in cucumber exposed to $\mathrm{Ca}\left(\mathrm{NO}_{3}\right)_{2}$ stress. Acta Physiol Plant 36:2845-2852

53. Zhang RM, Sun YK, Liu ZY, Jin W, Sun Y (2017) Effects of melatonin on seedling growth, mineral nutrition, and nitrogen metabolism in cucumber under nitrate stress. J Pineal Res 62:e12403

54. Zhen A, Bie ZL, Huang Y, Liu ZX, Li Q (2010) Effects of scion and rootstock genotypes on the anti-oxidant defense systems of grafted cucumber seedlings under $\mathrm{NaCl}$ stress. Soil Sci Plant Nutr 56:263-271

55. Zhen A, Zhang Z, Jin XQ, Liu T, Ren WQ, Hu XH (2018) Exogenous GABA application improves the $\mathrm{NO}_{3}{ }^{-}-\mathrm{N}$ absorption and assimilation in $\mathrm{Ca}\left(\mathrm{NO}_{3}\right)_{2}$-treated muskmelon seedlings. Sci Hortic 227:117-123

56. Zou X, Liu MY, Wu WH, Wang Y (2019) Phosphorylation at Ser28 stabilizes the Arabidopsis nitrate transporter NRT2.1 in response to nitrate limitation. J Integr Plant Biol 62:865-876

\section{Figures}


A

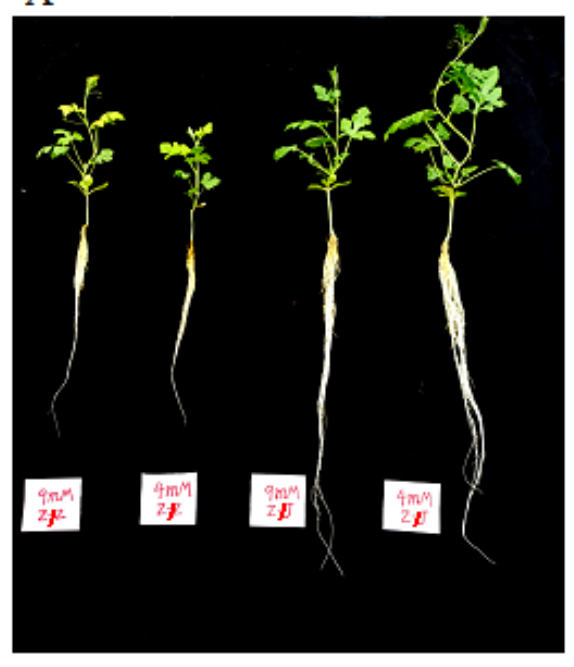

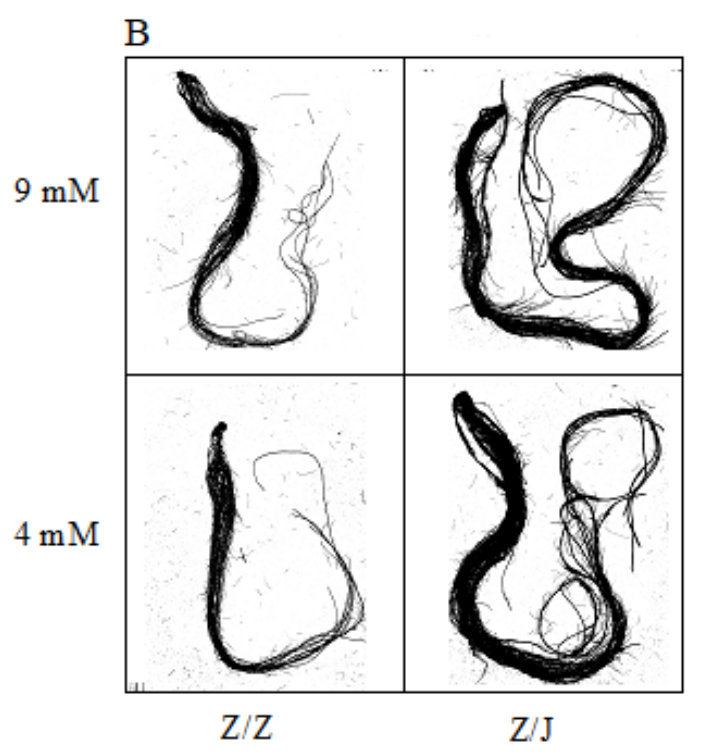

\section{Figure 1}

Plant growth (a) and root morphology (b) of grafted watermelon seedlings grown under $9 \mathrm{mM}$ and $4 \mathrm{mM} \mathrm{NO}_{3}{ }^{-} \mathrm{N}_{\text {conditions. }}$ $\mathrm{Z} / \mathrm{Z}$ : self-grafted watermelon seedlings; Z/J: rootstock-grafted watermelon seedlings

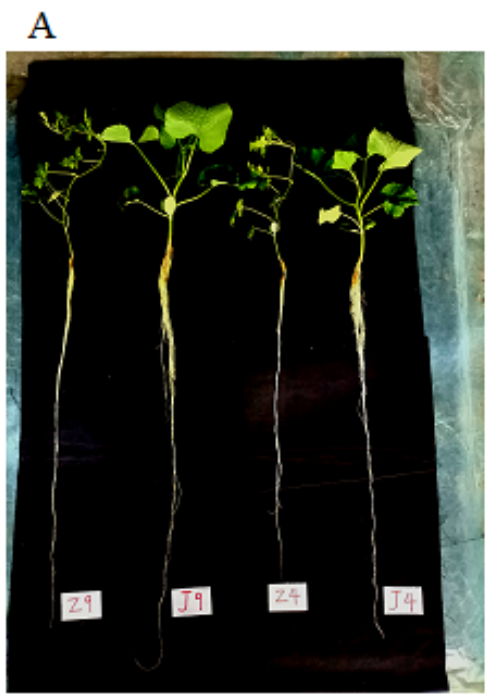

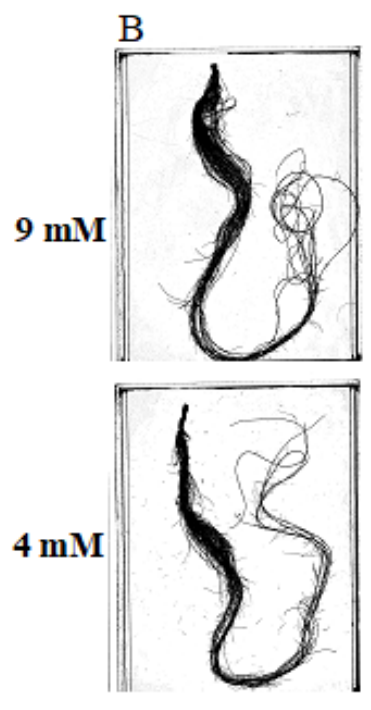

$\mathbf{Z}$
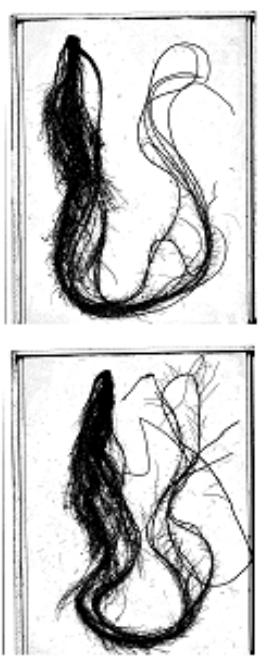

$\mathbf{J}$

Figure 2

Plant growth (a) and root morphology (b) of ungrafted watermelon and bottle gourd seedlings grown under $9 \mathrm{mM}$ and $4 \mathrm{mM}$ $\mathrm{NO}_{3}{ }^{-} \mathrm{N}$ conditions. Z: ungrafted watermelon seedlings; J: ungrafted bottle gourd seedlings 

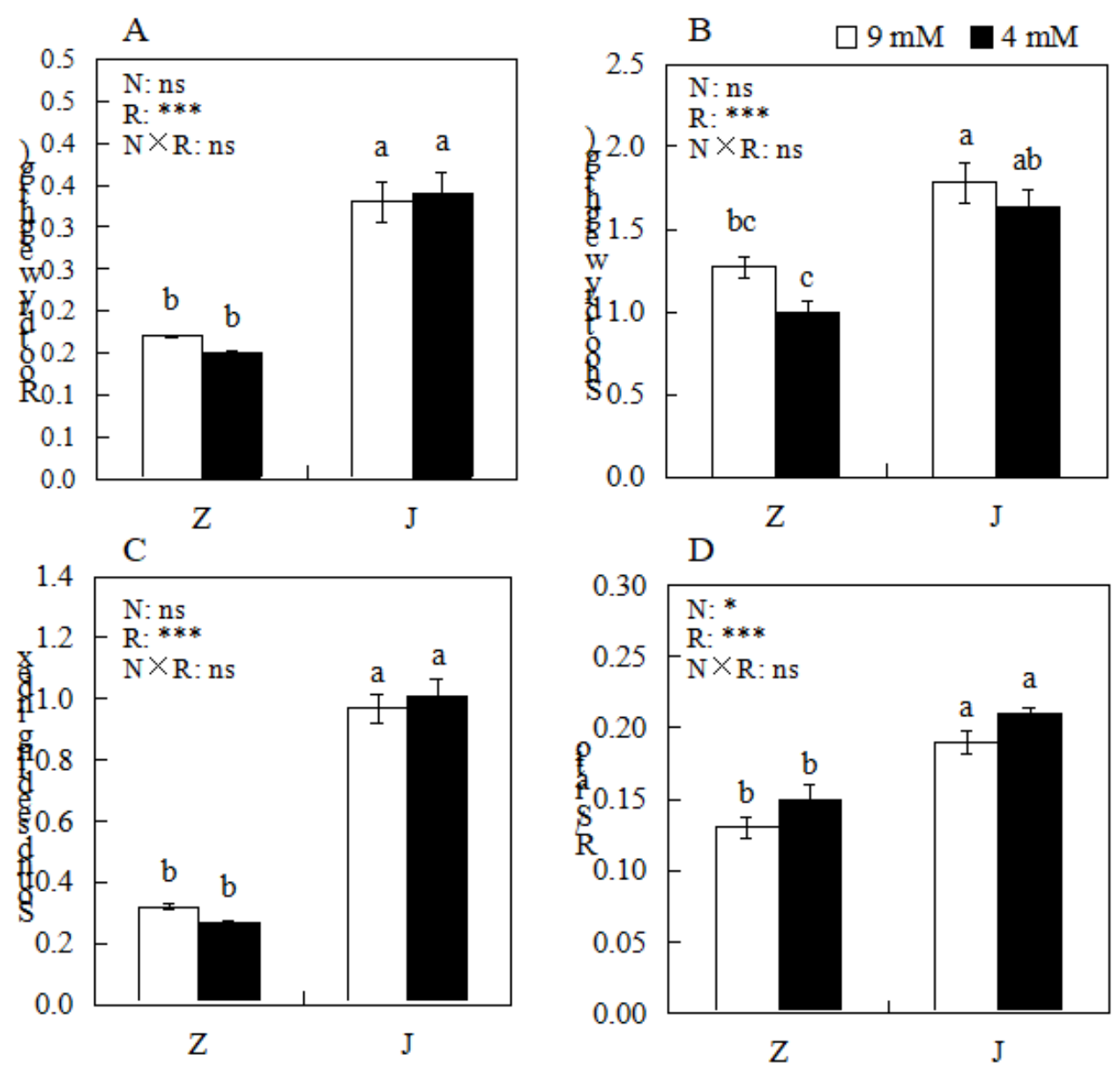

Figure 3

Root (a) and shoot (b) dry weight, sound seedling index (c), and R/S ratio (d) of ungrafted seedlings grown under $9 \mathrm{mM}$ and 4 $\mathrm{mM} \mathrm{NO}_{3}{ }^{-}-\mathrm{N}$ conditions. Values are mean $\pm \mathrm{SE}(n=3)$. Different letters indicate significant differences determined by Tukey test at $P<0.05$. Results of a two-way ANOVA are indicated, ${ }^{\star} P<0.05 ; * \star P<0.01 ; \star \star \star ~ P<0.001 ;$ ns, not significant. Z: ungrafted watermelon seedlings; J: ungrafted bottle gourd seedlings; $\mathrm{N}$ : $\mathrm{N}$ treatment; R: rootstock genotype; $\mathrm{N} \times \mathrm{G}$ : the interaction 
A
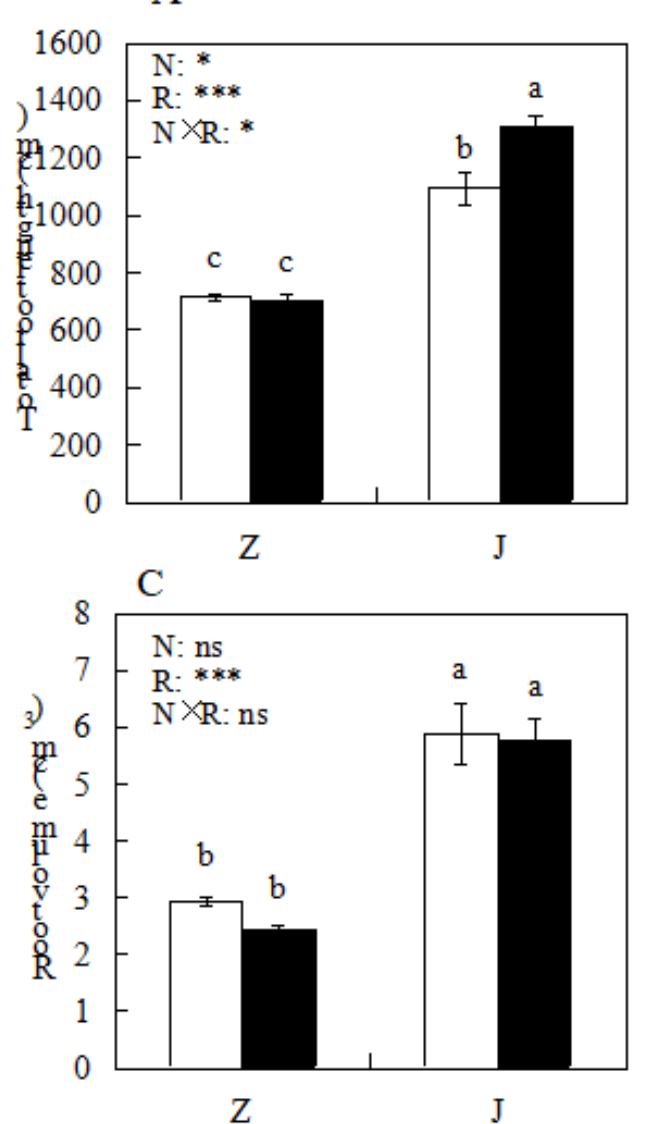

B
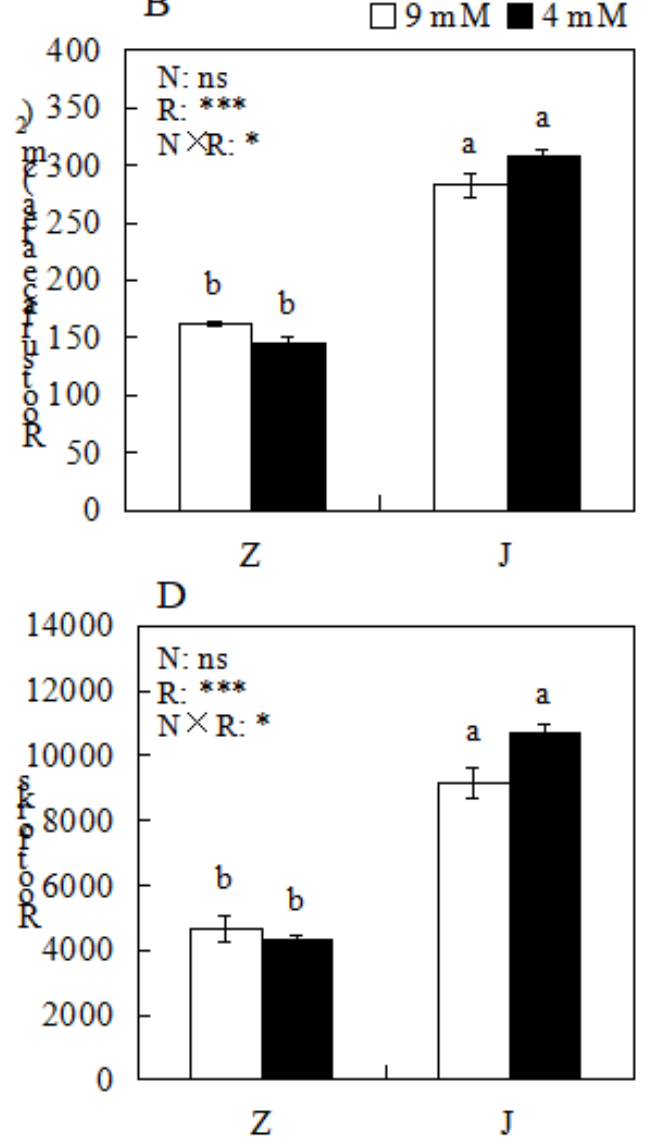

\section{Figure 4}

Total root length (a), root surface area (b), root volume (c), Root forks (d) of ungrafted seedlings grown under $9 \mathrm{mM}$ and $4 \mathrm{mM}$ $\mathrm{NO}_{3}{ }^{-}-\mathrm{N}$ conditions. Values are mean $\pm \mathrm{SE}(n=3)$. Different letters indicate significant differences determined by Tukey test at $P<0.05$. Results of a two-way ANOVA are indicated, ${ }^{\star} P<0.05$; $* \star P<0.01 ; * \star \star P<0.001$; ns, not significant. Z: ungrafted watermelon seedlings; J: ungrafted bottle gourd seedlings; $N$ : $N$ treatment; R: rootstock genotype; $N \times G$ : the interaction
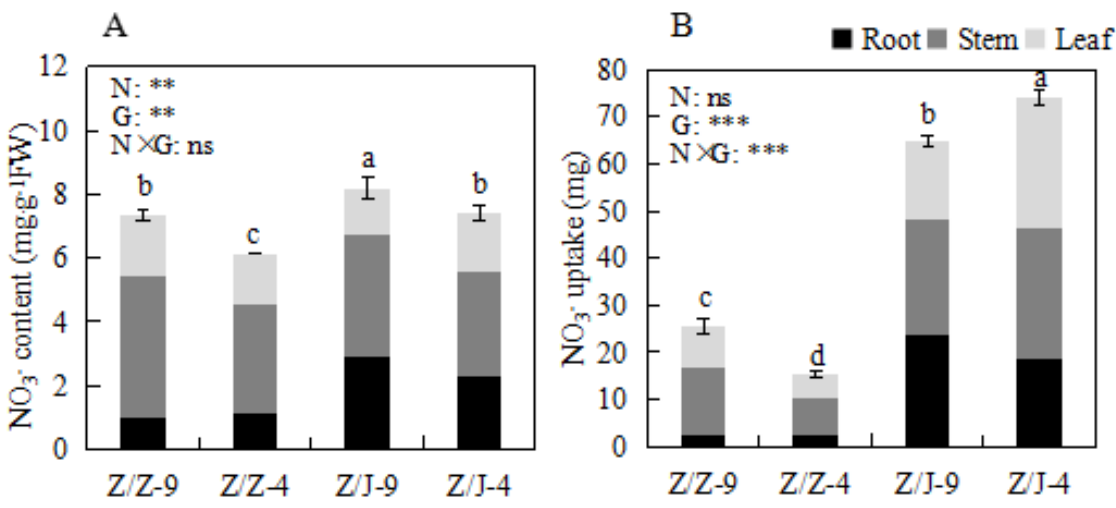

\section{Figure 5}

$\mathrm{NO}_{3}{ }^{-}$content (a) and $\mathrm{NO}_{3}{ }^{-}$uptake (b) in the roots, stems and leaves of self-grafted and rootstock-grafted watermelon seedlings under $9 \mathrm{mM}$ and $4 \mathrm{mM} \mathrm{NO}_{3}{ }^{-}-\mathrm{N}$ conditions. Values are mean $\pm \mathrm{SE}(n=3)$. Different letters indicate significant differences determined by Tukey test at $P<0.05$. Results of a two-way ANOVA are indicated, ${ }^{\star} P<0.05 ; * \star P<0.01 ; * \star * P<0.001 ; \mathrm{ns}$, not 
significant. Z/Z: self-grafted watermelon seedlings; Z/J: rootstock-grafted watermelon seedlings; N: N treatment; G: graft combination; $\mathrm{N} \times \mathrm{G}$ : the interaction; FW: Fresh weight
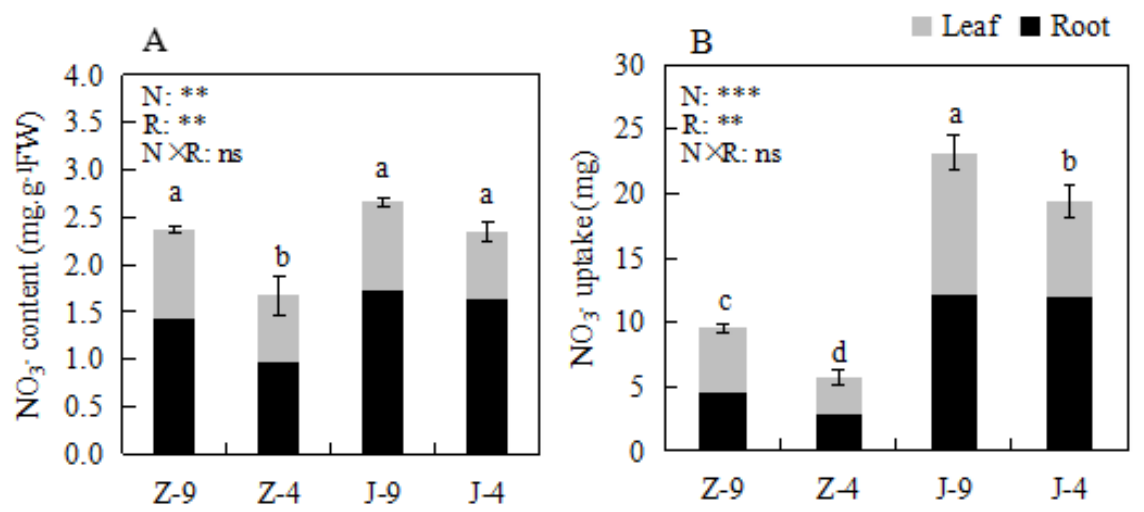

Figure 6

$\mathrm{NO}_{3}{ }^{-}$content (a) and $\mathrm{NO}_{3}{ }^{-}$uptake (b) in the roots and leaves of ungrafted seedlings under $9 \mathrm{mM}$ and $4 \mathrm{mM} \mathrm{NO}_{3}{ }^{-} \mathrm{N}_{\text {conditions. }}$ Values are mean $\pm \mathrm{SE}(n=3)$. Different letters indicate significant differences determined by Tukey test at $P<0.05$. Results of a two-way ANOVA are indicated, ${ }^{\star} P<0.05 ; * \star P<0.01 ; * \star \star ~ P<0.001 ;$ ns, not significant. Z: ungrafted watermelon seedlings; J: ungrafted bottle gourd seedlings; N: N treatment; R: rootstock genotype; N×G: the interaction; FW: Fresh weight
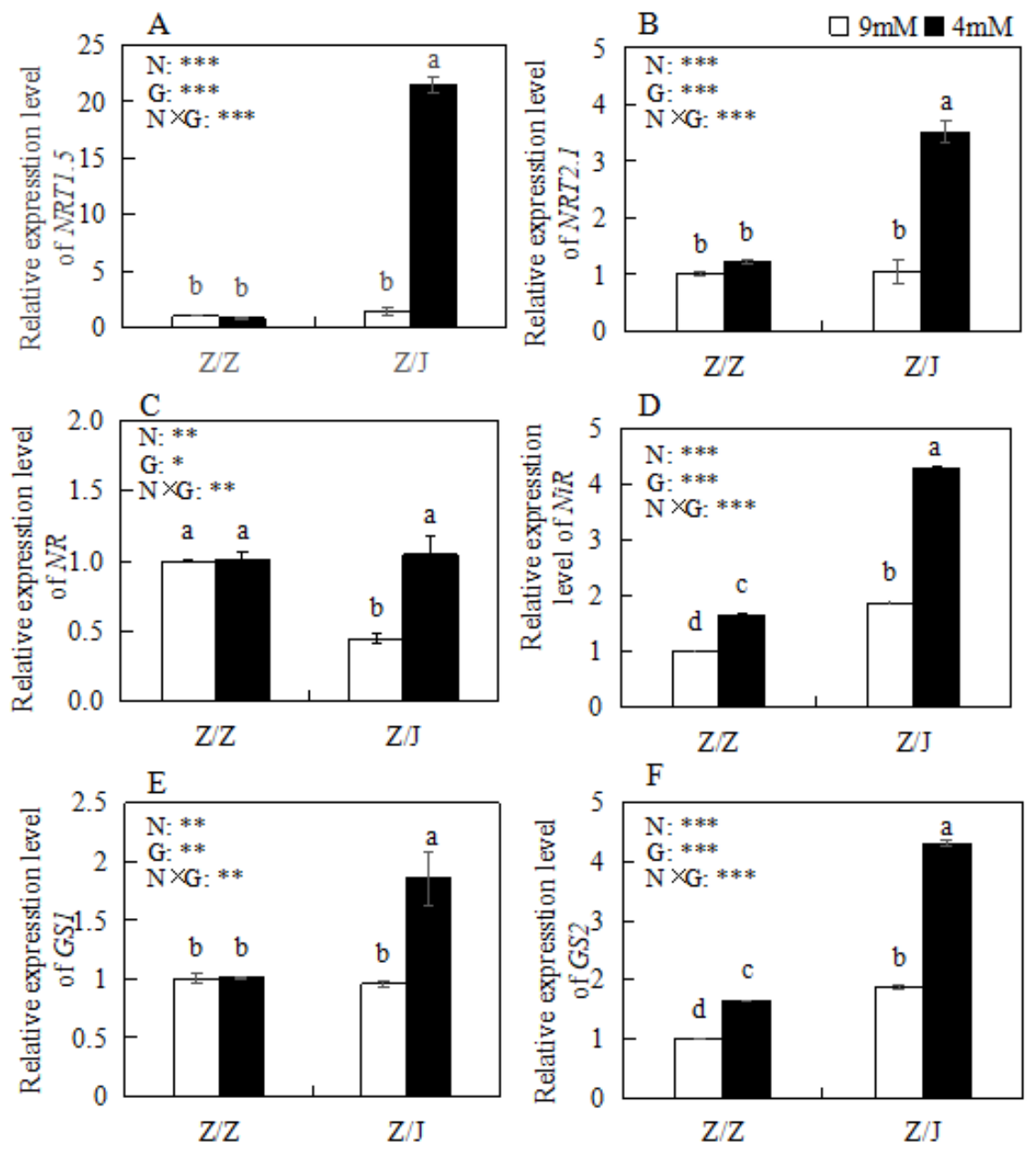

Figure 7 
Relative expression of nitrate transporter genes NRT1.5 (a) and NRT2.1 (b) in the roots, and nitrogen metabolism enzyme genes $N R(\mathrm{c}), N i R(\mathrm{~d}), G S 1$ (e) and GS2 (f) in the leaves of self-grafted and rootstock-grafted watermelon seedlings under $9 \mathrm{mM}$ and $4 \mathrm{mM} \mathrm{NO}_{3}{ }^{-} \mathrm{N}$ conditions. Values are mean $\pm \mathrm{SE}(n=3)$. Different letters indicate significant differences determined by Tukey test at $P<0.05$. Results of a two-way ANOVA are indicated, ${ }^{*} P<0.05 ; * \star P<0.01 ; * \star \star P<0.001$; ns, not significant. Z/Z: selfgrafted watermelon seedlings; Z/J: rootstock-grafted watermelon seedlings; $N$ : $N$ treatment; G: graft combination; $N \times G$ : the interaction

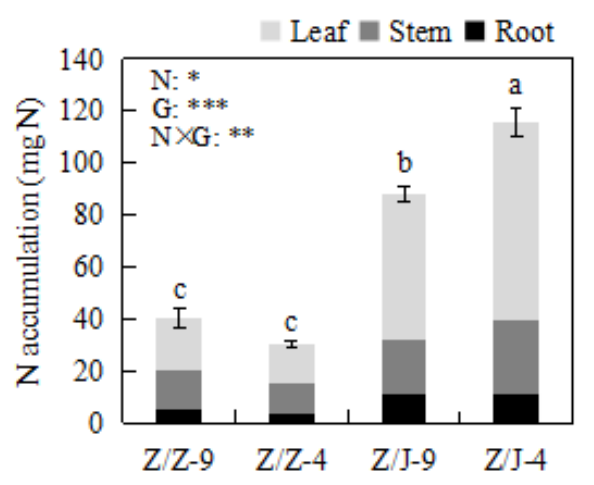

\section{Figure 8}

$\mathrm{N}$ accumulation in the root, stem and leaf of self-grafted and rootstock-grafted watermelon seedlings under $9 \mathrm{mM}$ and $4 \mathrm{mM}$ $\mathrm{NO}_{3}{ }^{-}-\mathrm{N}$ conditions. Values are mean $\pm \mathrm{SE}(n=3)$. Different letters indicate significant differences determined by Tukey test at $P<0.05$. Results of a two-way ANOVA are indicated, ${ }^{\star} P<0.05 ; * \star P<0.01 ; * \star * P<0.001 ;$ ns, not significant. Z/Z: self-grafted watermelon seedlings; Z/J: rootstock-grafted watermelon seedlings; N: N treatment; G: graft combination; N×G: the interaction 

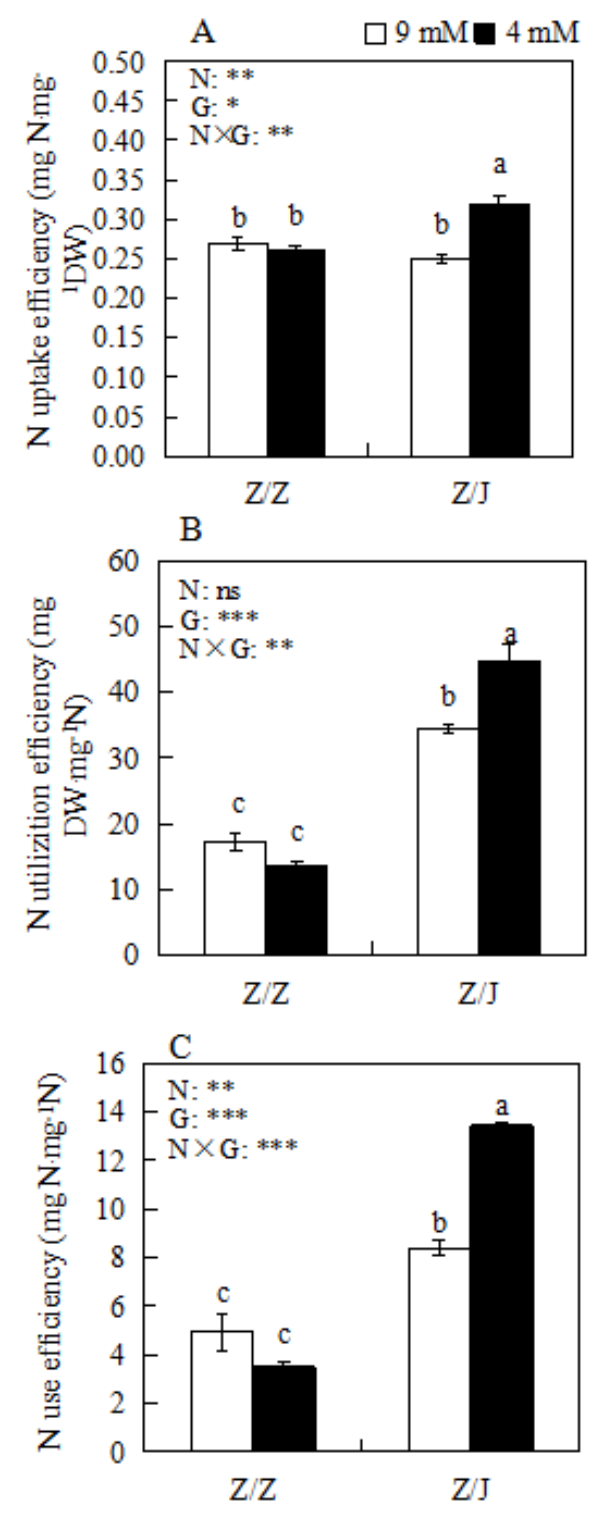

\section{Figure 9}

$\mathrm{N}$ uptake efficiency (a), $\mathrm{N}$ utilizition efficiency (b) and $\mathrm{N}$ use efficiency (c) of self-grafted and rootstock-grafted watermelon seedlings under $9 \mathrm{mM}$ and $4 \mathrm{mM} \mathrm{NO}_{3}{ }^{-} \mathrm{N}$ conditions. Values are mean $\pm \mathrm{SE}(n=3)$. Different letters indicate significant differences determined by Tukey test at $P<0.05$. Results of a two-way ANOVA are indicated, ${ }^{\star} P<0.05 ; * \star P<0.01 ; * \star \star ~ P<0.001 ; \mathrm{ns}$, not significant. Z/Z: self-grafted watermelon seedlings; Z/J: rootstock-grafted watermelon seedlings; N: N treatment; G: graft combination; N×G: the interaction; DW: Dry weight 

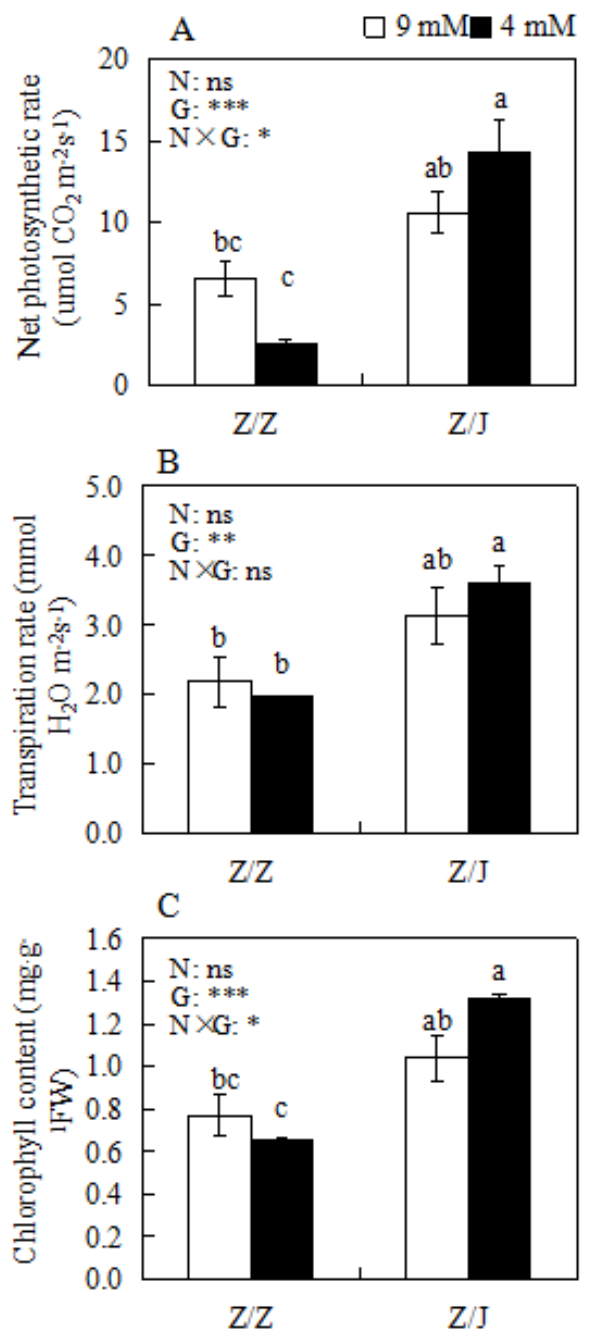

\section{Figure 10}

Net photosynthetic rate (a), Transpiration rate (b) and Chlorophyll content (c) of self-grafted and rootstock-grafted watermelon seedlings under $9 \mathrm{mM}$ and $4 \mathrm{mM} \mathrm{NO}_{3}{ }^{-}-\mathrm{N}$ conditions. Values are mean $\pm \mathrm{SE}(n=3)$. Different letters indicate significant differences determined by Tukey test at $P<0.05$. Results of a two-way ANOVA are indicated, ${ }^{\star} P<0.05 ; * \star P<0.01 ; * \star \star * 0.001 ; \mathrm{ns}$, not significant. Z/Z: self-grafted watermelon seedlings; Z/J: rootstock-grafted watermelon seedlings; $N$ : $N$ treatment; $\mathrm{G}$ : graft combination; $\mathrm{N} \times \mathrm{G}$ : the interaction 


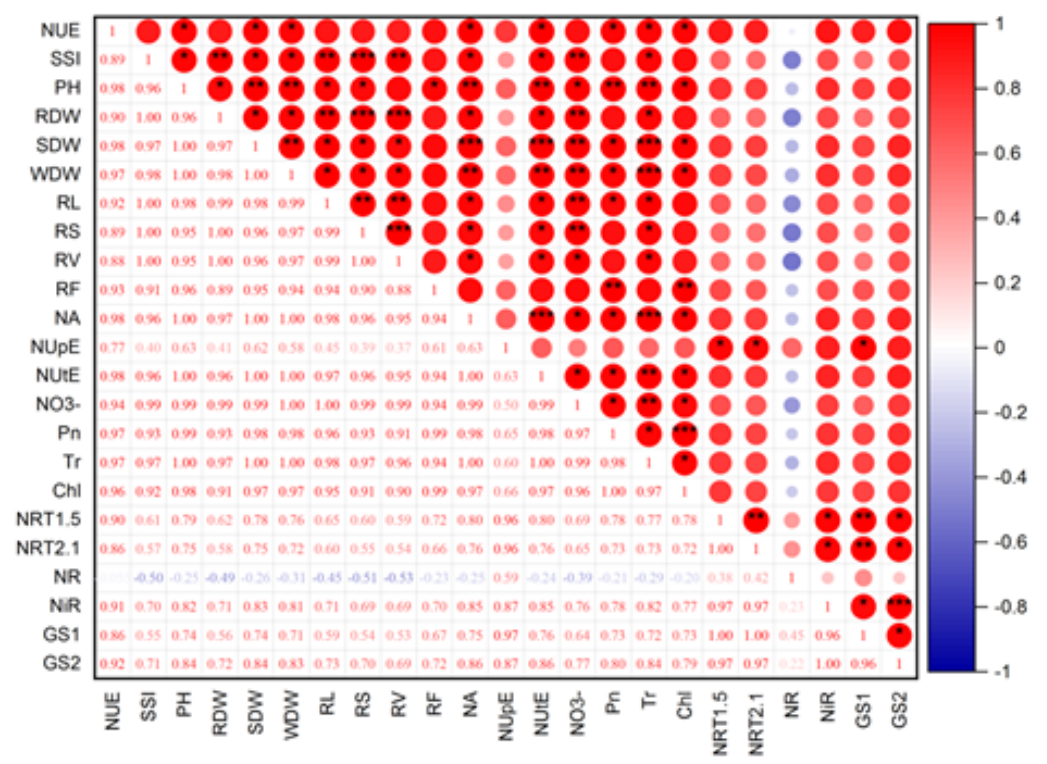

\section{Figure 11}

Pearson's correlation analysis between the NUE and the other parameters of the self-grafted and rootstock-grafted watermelon seedlings under $9 \mathrm{mM}$ and $4 \mathrm{mM} \mathrm{N}$ conditions. *, $* *$ and $* \star * ;$; Correlation is significant at the 0.05, 0.01 and 0.001 levels, respectively. NUE, nitrogen-use efficiency; SSI, sound seedling index; $\mathrm{PH}$, plant height; rDW, root dry weight; sDW, shoot dry weight; wDW, whole plant dry weight; RL, total root length; RS, root surface area; RV, root volume; RF, root forks; NA, N accumulation; $\mathrm{NUpE}$, nitrogen-uptake efficiency; $\mathrm{NUtE}$, nitrogen-utilizition efficiency; $\mathrm{NO}_{3}{ }^{-}$, whole plant $\mathrm{NO}_{3}{ }^{-}$uptake; $\mathrm{Pn}$, net photosynthetic rate; Tr, transpiration rate; Chl, chlorophyll content; NRT1.5 and NRT2.1, nitrate transporters genes; NR, nitrate reductase gene; NiR, nitrite reductase gene; GS1 and GS2, glutamine synthetase genes 